\title{
COMMENT: THE UNIVERSITY AND THE PUBLIC: THE RIGHT OF ACCESS BY NONSTUDENTS TO UNIVERSITY PROPERTY
}

A well-known agitator comes onto a University of California campus during a period of student unrest to attend a concert to which the public is invited. A nonstudent comes onto a campus to give a speecl supporting students protesting the conduct of the University administration. In both instances, under a new California law, Penal Code section 602.7, refusal to obey a request to leave the campus made by a University official constitutes a misdemeanor if it reasonably appears that the person is committing, or has entered for the purpose of committing, an act likely to interfere with the peaceful conduct of the University.

One response to the evolution of new "direct action" forms of social and political mass protest, particularly in the labor and civil rights fields, lias been the renewed interest in or increased enforcement of laws regulating activities such as loitering, ${ }^{1}$ breacl of the peace, ${ }^{2}$ criminal trespass, $^{3}$ and criminal conspiracy ${ }^{4}$ which are not ordinarily applied to political activity. Penal Code section 602.7 represents a legislative response to a particular period of turmoil-the "Free Speech" controversy at the Berkeley campus of the University of California in the autumn of $1964 .^{\circ}$

\footnotetext{
1 See, e.g., Shuttlesworth v. City of Birmingham, 382 U.S. 87 (1965); Thompson v. City of Louisville, 362 U.S. 199 (1960).

2 See, e.g., Cox v. Louisiana, 379 U.S. 536 (1965); Henry v. Rock Hill, 376 U.S. 776 (1964); Edwards v. South Carolina, 372 U.S. 229 (1963).

3 See, e.g., Griffin v. Maryland, 378 U.S. 130 (1964); Barr v. City of Columbia, 378 U.S. 146 (1964) (breach of the peace and trespass); Robinson v. Florida, 378 U.S. 153 (1964); Bouie v. City of Columbia, 378 U.S. 347 (1964); People v. Poe, 236 A.C.A. Supp. 722, 47 Cal. Rptr. 670, aff'd on rehearing, 236 A.C.A. Supp. 737, 47 Cal. Rptr. 679 (1965). See generally Schwelb, The Sit-in Demonstration: Criminal Trespass or Constitutional Right?, 36 N.Y.U.L. REv. 779 (1961); Note, The Use of Trespass Laws to Enforce Private Policies of Discrimination, 16 HASTINGS L.J. 445 (1965).

4 For a discussion recommending strict enforcenent of conspiracy laws and rather cavalierly dismissing serious objections to laws of this sort, see Note, Mass Demonstrations and Criminal Conspiracies, 16 Hastings L.J. 465 (1965).

5 For a list of other legislative proposals, see note 10 infra. Althougb the cases cited in notes 1-3 supra do not represent situations of direct action against universities, they are nevertheless significant in that they dealt with similar types of mass demonstrations. In addition, there is a close parallel between the civil rights cases and the choice of mass protest, primarily the sit-in in Sproul Hall, as a vehicle for the expression of student grievances. Not only were a significant number of students involved in the Free Speech Movement veterans of previous incidents of civil disobedience, but more importantly, the use of civil disobedience lay at the heart of the entire controversy. It was the University's position that the campus facilities not be used for the purpose of organizing "illegal" activities which was the central point of contention between students and administration, since the major portion of illegal activities sought to be organized on campus were typically the arrangements made for groups to participate in off-campus mass demonstrations protesting discriminatory housing, hiring practices, police treatment, and, subsequently, demonstrations evidencing dissatisfaction with
} 
The statute raises state and federal constitutional problems, particularly in first amendment areas, and suggests the need to evaluate the nature and himits of the public's riglit to obtain access to public property, and more particularly, to university and college campuses. This Comment will review the legislative history, discuss the constitutional problems presented, and consider generally the appropriateness of criminal trespass laws of this sort as a means of controlling conduct. ${ }^{6}$

I

\section{IEGISLATIVE HISTORY}

The final amended version of Assembly Bill 1920 of the 1965 Regular Session of the California Legislature, signed into law as an emergency measure on June 1, 1965, adds section 602.7 to the California Penal Code. $^{7}$

the course of United States foreign policy. See Byrne, Report on the University of California and Recommendations to the Special Committee of the Regents of the University of California, May 7, 1965 [hereinafter cited as Byrne Report with citation to the appropriate column and page of the report as reprinted in The Los Angeles Times of May 12, 1965]; cf. Hurwitt v. City of Oakland, 247 F. Supp. 995 (ND. Cal. 1965) (City of Oakland enjoined frons prohibiting peaceful march protesting Vietnam war); In re Bacon, 240 A.C.A. 34, 49 Cal. Rptr. 322, opinion modified and rehearing denied, 240 A.C.A. 323 (1966) (affirming order of juvenile court finding trespass, etc., violations in Sproul Hall sit-in of Deceinber 2, 1964).

${ }^{6}$ This Comment will not deal with problems of the internal government of students by university and college administrations. For literature on those problems, see Bibliograply infra this Symposium. The enforceability of Penal Code $\$ 602.7$ will not be explored at length. It has been suggested by one commentator, however, that, "In anything short of riot conditions, the real victims of Mulford's law will be the luckless flunkies appointed to enforce it. . . . It would be a nightmare of lies, false seizures, double entries, and certain provocation." Thompson, The Non-Student Left, 201 THE NATION 155 (1965).

7 Cal. Stats. 1965, ch. 475 . Penal Code $\$ 602.7$ reads as follows:

(a) In any case in which a person who is not a student or officer or employee of a state college or state university, and who is not required by his employment to be on the campus or any other facility owned, operated or controlled by the governing board of any such state college or state university, enters such campus or facility, and it reasonably appears to the chief administrative officer of such campus or facility or to an officer or employee designated by him to maintain order on such campus or facility that such person is conmitting any act likely to interfere with the peaceful conduct of the activities of such campus or facility or has entered such campus or facility for the purpose of committing any such act, the chief administrative officer or officer or employee designated by him to maintain order on such campus or facility may direct such person to leave such campus or facility, and if such person fails to do so, he is guilty of a misdemeanor.

(b) As used in this section:

(1) "State university" means the University of California, and includes any affiliated institution thereof and any campus or facility owned, operated or controlled by the Regents of the University of California.

(2) "State college" means any California state college administered by the Trustees of the California State Colleges. 
Assembly Bill 1920 was introduced by Assemblyman Don Mulford, in whose 16th Assembly District the Berkeley campus lies. ${ }^{8}$ Section 2 of the bill leaves hittle doubt that the ineasure was enacted in response to the Free Speech Movement controversy:

Sec. 2. This act is an urgency measure necessary for the immediate preservation of the public peace, health or safety within the meaning of Article IV of the Constitution and shall go into immediate effect. The facts constituting such necessity are:

Recent conduct on and about a campus of the University of California, instigated to a large extent by persons without affiliation or connection with the university, denionstrates clearly that legal sanctions must immediately be made available to the authorities to deal with disturbing intrusions by persons having no proper business on a campus of the university or of a state college. For this reason, the Legislature deems it injperative that this act go into immediate effect. ${ }^{\circ}$

Penal Code section 602.7 was only one of several legislative responses to the Berkeley turmoil. ${ }^{10}$ A large nonstudent population, typical with

(3) "Chief administrative officer" means the president of a state college or officer designated by the Regents of the University of California or pursuant to authority granted by the Regents of the University of California to administer and be the officer in charge of a campus or other facility owned, operated or controlled by the Regents of the University of California.

Sec. 2. (Urgency measure).

For text of section 2, which was not codified, see text arcompanying note 9 infra.

8 Assearbly WeEkry HistorX 3 (June 18, 1965); see Cax. Etectrons Code $\$ 30201$ (1).

DA legislative determination of urgency under article IV, $\S 1$ of the California constitution is final unless no declaration of facts constituting the emergency is included, or unless the statement of facts is so clearly insufficient that there is no reasonable doubt that the urgency does not exist. Azevedo v. Jordan, 237 A.C.A. 615, 619, 47 Cal. Rptr. 125, 128 (1965).

10 Other legislative measures proposed but not enacted during the Regular Session, 1965 were as follows: Assembly Bill 570 (forfeiture of state scholarships for convictions arising fronl participation in campus demonstrations), Assembly Bill 1962 (violation or attempted violation of rules promulgated by Regents of the University of California for buildings and grounds a misdemeanor), Assembly Const. Amend. 46 (proposed amendment of California constitution, art. IX, $\S 9$, imposing duty on Regents to protect academic freedom and delegating all intellectual aspects to faculty control), Assembly Concurrent Resolution 65 (request that Regents of University of California act to expel active participants in obscenity demonstration), Senate Bill 35 (misdemeanor to interfere with public or private educational institution by sit-in, or to refuse to depart after warning), Senate Bill 164 (hindrance to operation of public building a misdemeanor), Senate Bill 632 (expulsion of students participating in or aiding riots and disturbances), Senate Bill 633 (dismissal of teachers participating in or aiding riots and disturbances), Senate Bill 864 (misdemeanor to violate rules established by Regents for buildings and grounds) (passed by Senate, Senate Datcy Journal 3263 (June 3, 1965)), Senate Bill 1283 (discharge of faculty member or expulsion of student convicted of criminal offense on campus, to be effective only if Senate Constitutional Amendment 1 passed by people), Senate Const. Amend. 1 (proposed amendenent of California constitution, art. IX, $\$ 9$, to provide for legislative regulation of conduct and discipline of faculty and students of the Umiversity of California), Senate Const. Amend. 2 (proposed amendment of California constitution, art. IX, $\S 9$, to provide for expulsion of faculty member or student convicted of 
most urban universities, was seen as particularly active in the Berkeley case, and was regarded as a threat to University administration against which there existed no adequate sanctions. ${ }^{11}$

A.B. 1920 as introduced would have conferred unlimited discretion to eject outsiders:

Every person who, not being a student or officer or employee of a college or university, and who is not required by his employment to be on the campus of such college or university, goes upon such campus and refuses to leave when requested to do so by the head of such college or university, is guilty of a misdemeanor. ${ }^{12}$

The bill was referred to the Committee on Criminal Procedure which suggested amendments and recommended "do pass." At the second reading in the Assembly on April 1, 1965, the suggested amendments were adopted by the Assembly. ${ }^{13}$ These amendments added the language that required it to "reasonably appear" that the outsider be committing any act, or have "entered for the purpose of committing" any act "likely to interfere with the peaceful conduct of the activities of the state college or university" before his refusal to obey a request to leave constituted a misdemeanor.

At the third reading on April 8, 1965, minor amendments were made, but on April 12, 1965, the action of April 8th was rescinded and the bill again received a third reading at which time amendments added to the list of Assembly sponsors, expanded the coverage to include any "facility owned, operated, or controlled by the governing board" of the college or

a criminal offense during a campus disturbance), Senate Concurrent Resolution 7 (request to Regents of University of California to discipline students participating in Free Speech Movement disturbances), Senate Concurrent Resolution 8 (request to Regents of University of California to discharge faculty participating in Free Speech Movenient disturbances).

11 California Penal Code $\S 602(0)$, for example, refers only to trespass by remaining in public buildings after closing hours and after being requested to leave.

The actual extent of nonstudent involvement in the Free Speech Movement dispute has been questioned. The Byrne Subcommittee of the Forbes Committee of the Board of Regents of the University of California, which was commissioned to study the causes of the dispute, reported as follows: "We concluded that 'non-students' were not a crucial element in the disturbances or in the F.S.M. Of those arrested in Sproul Hall, for example, 87 percent were enrolled as students. Some of the 'non-students' were recent alumm, living near the university and, in some cases employed by it. Some were students who had dropped out of the university to work, but had retained their friendships on the campus and planned to return to fornal studies. Others were wives of students, particularly graduate students. All of these individuals were for all practical purposes part of the 'University Community." Byrne Report, p. 5, col. 2.

12 Assembly Bill 1920 (March 18, 1965). The history of A.B. 1920 is given in Asseandix WeEkCXY HISTORY 592 (June 18, 1965). A.B. 1920 was the subject of three opinions of the Legislative Counsel: No. 16922 (April 9, 1965); No. 17766 (April 30, 1965); and No. 20552 (May 4, 1965). No. 17766 is reprinted in Assemariy Dafly Journax 3443-48 (May 17, 1965).

13 Assembly DaIly Journal 1579-80 (April 1, 1965). 
university, and changed the language in an attempt to make the administration of the provisions of the bill congruent with the organizational structure of the University of California. ${ }^{14}$

On April 13 an amendenent was offered by Assemblyman Warren, which would have made a misdemeanor the malicious and wilful interference with the peaceful conduct of the activities of a state college or university by the specified conduct of "loud or unusual noise, tunultuous or offensive conduct, or by use of any vulgar, profane, or indecent language within the presence or hearing of women, or children, in a loud and boisterous manner."15

This proposed ainendment, which would have proscribed only specified objectionable conduct, was defeated by a vote of 52 to 18 . The urgency clause was adopted by a 62 to 14 vote, and A.B. 1920 was passed by the identical vote of 62 to $14 .^{16}$

A.B. 1920 received its first reading in the Senate on the same day, April 13, 1965, and was referred to the Judiciary Committee. At the second reading on April 26, 1965, a minor ainendinent was made to the text and additional sponsors were listed. ${ }^{17}$ On April 29, 1965, further minor ainendments reflecting the organization of the state college system were inade and inore co-authors were added. ${ }^{18}$

A serious legislative challenge to Assembly Bill 1920 occurred with the presentation of two proposed amendments by Senator Miller at the third reading on May 3, 1965. ${ }^{19}$ These amendments would have restricted the applicability of the section to those who entered and were committing "any act, not otherwise permitted by law or by university or state college rule or regulation, which interferes with the peaceful conduct" of the activities of the campus or facility concerned. The second proposed ainendment would have made the statute inapplicable to one who had merely entered the campus for the purpose of committing, as distinguisled from one who was committing, the proscribed act. ${ }^{20}$

Under the Miller proposal, as contrasted with the enacted bill, only one who had both "interfered," and who had also broken some otlier law or campus rule could be ejected. As this Comment will subsequently discuss, the juxtaposition of these alternatives highliglits many of the constitutional questions presented by section 602.7.

14 Id. at 1916-18 (April 12, 1965).

15 Id. at 1967-68 (April 13, 1965). Much of this language is taken from the existing disturbing of the peace statute. See CAL. PEN. CODE $\S 415$.

16 Assembir DaIty Journaz 1968 (April 13, 1965).

17 Senate Dafly Journal 1690 (April 26, 1965).

18 Id. at 1811 (April 29, 1965).

19 Id. at 1911 (May 3, 1965).

20 Ibid. See also Opinion of Legislative Counsel No. 20552 (May 4, 1965). 
A.B. 1920 was made a special order for May 18, at which time the proposed amendments of Senator Miller were defeated by a vote of 22 to 14 , and both the urgency clause and the bill itself, as previously amended, passed by a vote of 27 to $9 .^{21}$ The Assembly concurred in the Senate amendments on May 20, ${ }^{22}$ the bill was sent to the Governor on May 24, and was signed into law on June $1,1965 .^{23}$

21 Senate Datry Journat 2437-39 (May 18, 1965).

22 Assembly Dafty Journal 3690-91 (May 20, 1965).

${ }^{28}$ Cal Stats. 1965, ch. 475 . Section 602.7 is not the only California criminal trespass statute relating to public access to state college and university facilities. California Penal Code \$\$ 558-58.1 prohibit trespass on the University of California property and adjacent state waters at the Scripps Institute of Oceanography. Although extant since 1929, the statute has never been litigated at the appellate level. The two sections are the only sections under article 3, chapter 12 of the Penal Code, which is entitled "Trespass on Property belonging to the University of California." It might, on one land, be inferred that the codifiers envisioned a further series of provisions for trespass on University property of which this was only a part. On the other hand, this particular trespass provision was passed at the same time the legislature granted to the University the property to which the trespass provision applies. Cal. Stats. 1929, ch. 514, § 1, at 888. The legislature may attach such conditions to the management of land when it is the grantor, and the Regents of the University may consent to such conditions by accepting the grant. 3 OPs. CAL. ATr'Y GEN. 221 (1944). Since this constitutes an exception to the otherwise exclusive powers of the Regents to manage and control University property, it is arguable that in absence of the contemporaneous grant of land, the legislature would have been without power to pass even this trespass statute. See text accompanying notes $39-46$ infra.

The statute differs significantly from Penal Code $\S 602.7$ in that mere entry constitutes the trespass rather than conduct or entry for supposed specified purposes.

Statutes restricting access to universities are rare. New York Penal Law \& 722-b prohibits loitering in public schools by one not a parent or legal guardian of a pupil there enrolled. The statute was held constitutional in People v. Jolnnson, 6 N.Y.2d 549, 190 N.Y.S.2d 694, 161 N.E.2d 9 (1959), affirming 12 Misc. 2d 25, 176 N.Y.S.2d 744 (Dist. Ct. 1958), but was later construed to encompass only elementary and secondary schools below the collegiate level in People v. Ulogiares, 39 Misc. 2d 246, 240 N.Y.S.2d 429 (N.Y. City Crim. Ct. 1963). The above limitation is consistent with the Johnson case, supra, which emphasized the necessity for and justification of the law in terms of protection of innocent and immature school children. The New York statute did not, however, allow conviction of one who, though be was not a parent or legal guardian of an enrolled pupil, came on to school property for the purpose of protesting against alleged racial discrimination in the school district, where clear and present danger of actual disruption was not slown. See People ex rel. Bailey v. Dennis, 208 N.Y.S.2d 522 (New Rochelle City Ct. 1960), noted in 12 SyRACuSE L. Rev. 519 (1961).

CAL. PEN. CODE \& 602.7 occupies a point midway between strict trespass laws and laws of the loitering, disorderly conduct, or breach of the peace variety, since it is conduct after entry-refusing to leave when requested-which constitutes the misdemeanor. Whether this request to depart is to be regarded as controlled by the same standards as finding a breach of the peace, or whether it is more properly analogized to the termination of consent to be present in the civil law of trespass is not clear.

It has been suggested that since the public has no proprietary right of access to public property, particularly to property dedicated to a particular use, the legislature may specify termination of entry on any conditions it imposes. See Opinion of Legislative Counsel No. 17766 (April 30, 1965), reprinted in Assemably DaII Journar 3443, 3445 (May 17, 1965). 
II

\section{STATUTORY INTERPRETATION}

The exact meaning of Penal Code section 602.7 and its intended scope are uncertain. Problems may arise in attempting to determine who is not a "student," in determining the permissible extent of delegation by the chief administrative officer, and in determining the ambit of the discretion given to exclude individuals from campus premises. ${ }^{24}$

\section{A. Students}

The statute exempts from its provisions persons who are students, officers, or employees of a state college or university and who are required by their employment to be on a campus or facility of the college or university. ${ }^{25}$ The term "student" is not defined in section 602.7 . Is a student enrolled at a particular California university or state college campus guilty of a misdemeanor if he refuses to obey a request to leave another state college or university campus? The exemption is for "a student . . o of a state college or state university." Section 602.7 (b)(1) defines "state university" as the University of California, including "any affiliated institution thereof and any campus or facility owned, operated or controlled by the Regents of the University of California." "State College" includes any California state college administered by the trustees of the California State Colleges. ${ }^{26} \mathrm{An}$ anbiguity is created by referring to a student of a university or college and then defining university and college to include all campuses: Are all students, or merely those enrolled at the particular campus ("such campus") concerned exempted? ${ }^{27}$

24 The statute proscribes only conduct interfering with the campus; its terms do not cover activities organized on campus which lead to illegal or disruptive conduct elsewhere.

${ }^{25}$ CAL. PEN. CODE $\& 602.7$ (a). A literal reading of the exemption does not disclose whether the last clause purports to create an additional class of exempted persons; or whether it states an additional requirement for the student, officer, or employee; or whether it attempts to do both. The necessity for employees of private contractors to perform tasks on state college and university campuses, and the awkwardness of speaking of a student's studies as "employment" suggest that this is a fourth category of exempted persons, but wording in the conjunctive rather than in the alternative at least creates an ambiguity.

26 CAL. PEN. CODE $\& 602.7(\mathrm{~b})(2)$. The provisions regarding the organization of the California State Colleges and the Trustees of the California State Colleges are set forth in Car. EDUC. CODE \$§ 23600-5352.

27 For the purposes of the policies and regulations relating to the use of facilities of the University of California by students and student organizations, "student" is defined as "one who is regularly enrolled at a campus of the University of Califormia or who has completed the immediately preceding term and is eligible for re-enrollment." University of Cahifornia, Policies Relating to Students and Student Organizations, Use of University Facilities, and Non-Discrimination 4, July 1, 1965. Arguably, this definition contains the same ambiguity as Penal Code $\S 602.7$ as regards the status of a student on a campus other than that in which 
The purpose of the act, as stated in section 2 of A.B. 1920, is to control conduct by those "without affiliation or connection with the university," and who "have no proper business on a campus of the university or of a state college." If disciplinary jurisdiction over students is imposed at the campus level, any University-imposed discipline for misconduct occurring outside of the student's lome campus would present difficult problems of pre-emption, and jurisdictional conflict, so that if control of activities occurring on a campus is the objective, a definition of "student" which exempts from section 602.7's prohibition all of those enrolled at any state university or college campus is too broad.

An examination of the purposes of the act, as stated in section 2, might lead one to inconsistent conclusions. A "student" may have "affiliation" with the state college or umiversity systen and yet be regarded as having no "proper business," in a narrow sense, on another campus. But if "affiliation or connection" must be read in conjunction with a specific cainpus, then many University students making use of intercampus privileges would not fall within the exemption, even though the granting of reciprocal privileges by the University itself constitutes a recognition that students may have "proper business" on another campus. ${ }^{28}$

Presumably, "student" does not include recent alumni, college dropouts intending to return to study, spouses of students, or arguably, those whose University course and residence requirements have been completed, but who retain hibrary or other privileges while completing a dissertation. Yet these categories include persons who are, as one study has reported, "for all practical purposes, part of the university community."20

\section{B. Chief Administrative Officer}

The statute may be invoked by the chief administrative officer of the campus or facility, or by "an officer or employee designated by him to maintain order on such campus or facility. ${ }^{\prime 30}$ The chief administrative officer is defined as the president of a state college or the officer designated by the Regents of the University of Cahfornia or pursuant to authority granted by the Regents of the University of California to administer and

he is registered. It is, in any event, unclear whether this definition would be controlling in construing the statutory exemption.

28 Intercanıpus privileges of University students include: (1) the cashing of small checks, (2) the use of student union facilities, (3) the use of gymnasiums and other recreational and cultural facilities, (4) care at the Student Health Center, (5) use of hbraries, (6) use of services of Placement Center. University of California, supra note 27, at 11 (app. A).

Similar argunients apply to exemptions from the statute for "officers" and "employees." See, e.g., CAL. EDUC. CODE $\$ 22553$ (college teachers may be authorized to use facilities of another campus).

20 Byrne Report, p. 5, col. 2.

30 CAI. PEN. CODE $\$ 602.7$ (a). 
be the officer in charge of a campus or other facility owned, operated, or controlled by the Regents of the University of California. ${ }^{31}$ The extent of the permissible subdelegation of authority is somewhat unclear, particularly since under the state constitution the Regents of the University of California have full powers of organization and management over University property. ${ }^{32}$ Must one designated to maintain order be explicitly so designated for purposes of this statute, or is this power given to those already designated for more general campus policing? Powers are already given by statute to the Regents of the University of California ${ }^{33}$ and to the Trustees of the California State Colleges ${ }^{34}$ to appoint persons to constitute peace officers or a security patrol on the campuses and facilities owned, operated, controlled, or administered by them. Penal Code section 602.7 does not indicate whether those appointed in accordance with the pre-existing statutes are the proper, primary, or only officials authorized to request an outsider to leave the campus.

\section{Standards of Discretion}

The authorized official may direct a nonexempted person to leave when it "reasonably appears" to that particular official that such a person is committing, or las "entered the campus or facility for the purpose of conmitting" any "act likely to interfere with the peaceful conduct of the activities of sucl campus or facility."135 Thus it is the officer's appreliension that an act, or purposive entry for commission of an act, constitutes a likelihood of interference rather than an actual, present interference which is the enabling condition.

The apparent intent of the legislature, at least as it is evidenced by rejection of clarifying amendments in both the Assembly and the Senate, ${ }^{36}$

31 Cad. Pen. Code $\$$ 602.7(b) (3).

32 CAL. Const. art. IX, $\$ 9$.

33 CaL. Educ. Code $\$ 23501$.

34 CaI. Educ. Code $\$ 24651$.

${ }^{35}$ CAL. PEN. CODE $\S 602.7$ (a). Any statute is subject to unique interpretation in light of its particular structure or purposes; lowever, some guidance to the meaning of the standards "reasonably appears," and "likely to intefere" might be suggested by decisions of the California courts in construing other statutes. The word "appears" as used in connection with Penal Code $\S 872$ (degree of proof of guilt required-means to "seen reasonably probable" that the crime has been conımitted. Kind v. Superior Court, 143 Cal. App. 2d 100, 102, 299 P.2d 414, 416 (1956)). Thus "reasonably appears" in $\$ 602.7$ would seem to be redundant, since reasonableness is inherent in the meaning of "appears." In a civil context an event has been held to be "likely" when it is "probable." Nevis v. Pacific Gas \& Elec. Co., 43 Cal. 2d 626, 632, 275 P.2d 761, 765 (1954) ("likelihood means probability, not possibility"); Hoy v. Tornick, 199 Cal. 545, 554, 250 Pac. 565, 569 (1926); Horning v. Gerlach, 139 Cal. App. 2d 470, 473, 34 P.2d 504, 505 (1954).

${ }^{36}$ See text accompanying notes 15-21 supra. 
is to extend the reach of the statute to regulate conduct at the very threshold of potentially illegal activity.

The official's determination necessitates an ad hoc judgment both as to what constitutes peaceful conduct of the campus or facility concerned, ${ }^{37}$ and as to the motive of one who has entered "for the purpose" of committing the proscribed act. The word "act" is nowhere defined, and the wording of the statute does not exclude the possibility that speech-type conduct may fall within the category of acts deemed to constitute a likely interference. Neither the seriousness of the interference nor any enumerated classifications of acts are specified as conditions controling the exercise of the administrator's power.

The statute by its terms makes it not unlikely that the situation envisioned at the beginning of this Comment could occur: that a nonstudent could be ejected from college or university grounds for acts or speeches which otherwise comply with "time, place, and manner" rules set down by the institution for its students. ${ }^{38}$

III

\section{CONSTITUTIONAL AUTONOMY OF THE REGENTS}

Can section 602.7 be applied to the Umiversity of California? Article IX, section 9 of the constitution of California gives the University independent constitutional status as a public trust to be administered by the corporation known as the Regents of the University of California, which corporation is given "full powers of organization and government, subject only to such legislative control as may be necessary to insure compliance with the terms of the endowments of the university and the security of its funds." The corporation is vested with the legal title and the power of management and disposition of property owned by the University or held for its benefit. ${ }^{30}$ This status as a constitutional corporation

$\mathbf{3 7}$ The types of conduct likely to interfere vary as widely as the nature of the many facilities which are owned, operated, or controlled by the governing boards of the colleges or universities. See Linde, Campus Law: Berkeley Viewed from Eugene, 54 CALIF. L. Rev. 40, 55-54 n.28 (1966).

38 University policies presently require campus visitors to adhere to standards of conduct applicable to students, and to abide by University-wide policies and campus regulations while on University property. University of California, supra note 27 , at $\S$ III(B). If such rules were held to be a declaration by the University as to what is not an interference with its proper functioning, conviction for refusal to desist from an act not in violation of campus rules might constitute the "indefensible sort of entrapment" held to be invalid in Cox v. Louisiana, 379 U.S. 559 (1965). Penal Code $\S 602.7$ does not, however, refer to campus rules; indeed, a proposed aniendment to that effect was rejected by the Senate. See text accompanying notes 19-21 supra.

30 CAL. Const. art. IX, \& 9. 
makes the University of California, in effect, a fourth branch of the state government, ${ }^{40}$ and orders of the Regents within their constitutional powers have the force of statutes. ${ }^{41}$

By vesting the power to create a misdemeanor under the specified conditions of the statute in the chief administrative officer of the campus or facility in question rather than directly in the Board of Regents, the legislature has arguably failed to respect the constitutional power of the Regents to organize and govern the University of California. ${ }^{42}$

Under the constitution the legislature may control the corporation only to insure compliance with the terms of its endowments and the security of its funds. The only exception to that rule is stated in Tolman v. Underhill, ${ }^{43}$ which lield that laws passed by the legislature under its general police power will prevail over regulations made by the Regents with regard to matters which are not exclusively University affairs. In the Tolman case, it was found that the loyalty of teacliers at the University is "not merely a matter involving the internal affairs of that institution but is a subject of general statewide concern." ${ }^{\prime 44}$ Thus the loyalty oath imposed by the state was held to occupy exclusively a field which required uniformity of treatment and to preclude imposition of an additional oath by the Regents. ${ }^{45}$ The Tolman criteria, that the matter not be

40 Hamilton v. Regents of the Univ. of Cal., 293 U.S. 245, 257-58 (1934); Newmarker v. Regents of the Univ. of Cal., 160 Cal. App. 2d 640, 325 P.2d 558 (1958); Wallace v. Regents of the Univ. of Cal., 75 Cal. App. 274, 277, 242 Pac. 892, 894 (1925); Williams v. Wheeler, 23 Cal. App. 619, 138 Pac. 937 (1913); 30 Ops. CAX. ATr'y GEN. 162 (1957). The organization and legal status of the University of California and the California State Colleges is discussed in relation to problems of religion and higher education in Louisell \& Jackson, Religion, Theology, and Public Higher Education, 50 CAJIF. L. REv. 751, 783-92 (1962).

For a compilation of constitutional provisions and cases dealing with universities of other states which have the status of constitutional corporations, see Note, State UniversitiesLegislative Control of a Constitutional Corporation, 55 Micr. L. REv. 728 n.2 (1957). See also Newman, The Legai Position of the University of Nevada (1963); Peabody, The Legal Status of the University of Moine, 13 MAINE L. Rev. 187 (1920).

41 Hamilton v. Regents of the Univ. of Cal., supra note 40, at 258.

42 Legislative enactments dealing with the University of California have generally been only of an enabling nature, delegating powers directly to the Regents rather than to the administrators under jurisdiction of the Regents. See, e.g., CaL. Edvc. Code $\$ \S 2310$ (power to revoke scholarships), 23151 (power of condenination), 23201 (power to withdraw funds), 23351-55 (assent and authorization of Regents required). The discussion assumes that the legislature has the power to regulate the California State Colleges in a nianner which would be constitutionally impermissible if apphied to the University of California. See CAx. EDUC. CODE $\$ \S 23600-5352$.

$4339 \mathrm{Cal} .2 \mathrm{~d} 708,249$ P.2d 280 (1952).

44 Id. at 712,249 P.2d at 282.

45 Id. at 713,249 P.2d at 283. The particular posture of this case, the effect of which was to outlaw the additional oath, has led Chief Justice Traynor to characterize then Chief Justice Gibson's opimion as of "far-reaching significance in the area of political freedoms." Traynor, Phil Sheridan Gibson, 12 U.C.I.A.L. REv. 8, 11 (1964). 
an exclusive University affair, and that it be a subject of general statewide concern, are not wholly satisfactory standards by which to test the University of California's constitutional independence from the legislature. Virtually every event at the University is, in some sense, of general statewide concern, as the present statute and the general public reaction to the 1964-65 free speech crisis amply illustrate. Similarly the question of what is an exclusively Umiversity affair would seem to allow of great variation in interpretation. ${ }^{46}$

Tolman is a good example of a subject of statewide concern-loyalty and internal security. The same would be true of a criminal statute of general applicability dealing with larceny or burglary which in its general coverage included University land. Section 602.7, however, does not purport to be of general statewide applicability.

The present statute deals only with conduct on campuses or facilities of the University over whicls the Regents have sole powers of organization and control. Some conduct proscribable under the statute is arguably not otherwise susceptible of statewide police power regulation. Even given the Tolman limitation, therefore, the statutory grant seems an impermissible incursion into a province constitutionally reserved to the Regents of the University of Cahifornia.

\section{IV}

\section{CONSTITUTIONAL CONSIDERATIONS}

In 1895 if Judge Holmes had been faced with a statute either absolutely or conditionally forbidding all persons from entering any state educational property except for educational purposes, he might have argued that no right of the public would be infringed by absolute exclu-

46 The problems presented are analogous to those involved in defining the proper relationship between state legislative powers and local "home rule" power to regulate "municipal affairs." See CaI. Const. art. XI, $\S \S 6,11,12,13$. The courts have been unable to ascribe any fixed content to the constitutional concept of municipal affairs. Pacific Tel. \& Tel. Co. v. City \& County of San Francisco, 51 Cal. 2d 766, 771, 336 P.2d 514, 517 (1959). The courts have recognized a tripartite division of legislative subject nuatter: (1) affairs exclusively of mumicipal concern, (2) affairs exclusively of state concern, and (3) affairs of both municipal and state concern. In re Hubbard, 62 Cal. 2d 119, 127, 396 P.2d 809, 814, 41 Cal. Rptr. 393, 398 (1964); Note, 53 CAIIF. L. REv. 902 (1965). The municipality has exclusive legislative power over subject nuatter of exclusive nuunicipal concern. Cole v. City of Los Angeles, 180 Cal. 617, 182 Pac. 436 (1919); Civic Center Ass'n v. Railroad Conim'n, 175 Cal. 441, 166 Pac. 351 (1917). Can the legislature merely by expressing "statewide" concern, remove an issue from the municipal affairs domain and place it in the joint concern category and then, by further enactments occupy the field and pre-enipt local regulatory powers? If expression of legislative intent were to be decisive in the case of the University of California, little independence would remain fron legislative regulation in spite of the specifics of article IX, $\S 9$. For a general survey of the problems presented by nunicipal home rule powers and state legislative pre-emption, see Note, 53 CALIF. L. REv. 902 (1965). 
sion and that therefore the legislature might impose any conditions upon its use by outsiders. ${ }^{47}$ The assumption that the power to exclude necessarily establishes the authority to specify any conditions for termination of use-that "the greater power contains the lesser"48-must be examined carefully in the light of developing constitutional doctrines.

The "lesser" power to condition the use of public places has been limited by guarantees of due process, equal protection, and the first amendment, even when the power of a state to hmit or forbid public use of public places is expressly conceded or an issue left undecided..$^{40}$

Moreover, the "greater power" to exclude the public from places appropriate to the exercise of first amendment freedoms is itself subject to question, particularly in light of the developing concepts of "quasi-public" property. Even private property owners may not, in given circumstances, invoke otherwise valid trespass laws to exclude outsiders entering that private property to exercise a constitutionally protected form of expression. ${ }^{50}$

The following sections of this Comment will first explore the validity of section 602.7 as an exercise of the lesser power to exclude outsiders under specified conditions. The statute raises constitutional questions of notice under the due process clause, problems related to equality of access under the equal protection clause, and problems of statutory vagueness, delegation of discretionary licensing power, and potential deterrence of protected expression under the first amendment.

Part V of this Comment will consider the extent to which any constitutional deficiencies of section 602.7 might be vitiated by a claim that state college or university property is an inappropriate place for the exercise by members of the public of otherwise constitutionally protected liberties. This inquiry in turn requires an examination of the factors which underhe judicial determinations of the suitability of any property, public or private, for the exercise of such rights and which compel the title lolder to open the property to those asserting a first amendment claim.

\section{A. Due Process: Adequate Notice}

The fourteenth amendment due process clause not only compels the state and its agencies to respect first amendment guarantees, ${ }^{61}$ but also, under the "void for vagueness" doctrine, ${ }^{52}$ requires penal statutes to pro-

\footnotetext{
${ }^{47}$ See Commonwealth v. Davis, 162 Mass. 510, 39 N.E. 113 (1895), aff'd, Davis v. Massachusetts, 167 U.S. 43 (1897).

48 Davis v. Massachusetts, supre note 47 , at 48.

40 See, e.g., Cox v. Louisiana, 379 U.S. 536; Cox v. Louisiana, 379 U.S. 559 (1965) Edwards v. South Carolina, 372 U.S. 229 (1963).

${ }^{50}$ See text accompanying notes $130-42$ infra.

51 See text accompanying notes 68-114 infra.

52 For a discussion of this and related doctrines, see Collings, Unconstitutional Uncer-
} 
vide fair warning to the individual that certain conduct is proscribed ${ }^{53}$ and proper standards by which his guilt may subsequently be adjudicated. ${ }^{54}$

The misdemeanor under section 602.7 consists in refusing to obey the authorized request to leave the campus. To be guilty of a misdemeanor, the defendant must have known of the request and refused to comply. In this respect, the warming and the standards by which guilt may be adjudicated are definite. The enabling condition for such a request, however, is not the individual's general mens rea or his specific intent to disrupt, but rather that it "reasonably appears" to the officer that the person is committing, or has entered for the purpose of committing, an act likely to interfere with the peaceful conduct of campus activities. ${ }^{50}$ Under such circumstances, there is at least a question whether the standards given are sufficiently definite to enable a jury to determineexcept arbitrarily-whether the request was validly invoked, ${ }^{56}$ and whether they are sufficiently definite to apprise one entering the campus that his conduct or purpose can, in any circumstances, legitimately be interpreted by the official as tending to interfere.

"Notice" objections to section 602.7 also arise from the uncertain scope of the exemptions for students, officers, and employees. ${ }^{57}$ Even if the proscribed conduct-refusal to depart-were to be sufficiently clear, the statute miglit not give fair warning to those who have some colorable claim to use the university or college facilities. ${ }^{58}$

\section{B. Equal Protection}

It might be asserted that the statute violates the equal protection clause of the fourteenth amendment, which requires that statutes treat abike all persons similarly situated with respect to the particular statu-

tainty, 40 CORNeLI L.Q. 195 (1955); Amsterdam, The Void-for-Vagueness Doctrine in the Suprenie Court, 109 U. PA. L. REV. 67 (1960).

53 E.g., Baggett v. Bullitt, 377 U.S. 360 (1964); Cramp v. Board of Pub. Instruction, 368 U.S. 278 (1961); United States v. Harriss, 347 U.S. 612, 617 (1954); Lanzetta v. New Jersey, 306 U.S. 451 (1939); Connally v. General Constr. Co., 269 U.S. 385 (1926); Katzev v. County of Los Angeles, 52 Cal. 2d 360, 370, 341 P.2d 310, 317 (1959) (statutory overbreadth); cf. Bouie v. City of Columbia, 378 U.S. 347 (1964).

54 Giaccio v. Pennsylvania, 382 U.S. 399 (1966) (no standards for jury's imposition of court costs); Screws v. United States, 325 U.S. 91, 151-52 (1945) (dissenting opinion); Freund, The Supreme Court and Civil Liberties, 4 VAND. L. Rev. 533, 541 (1951); Note, 62 HARv. L. Rev. 77 (1948).

50 Penal Code $\$ 602.7$ is thus distinguishable from a narrowly drawn trespass statute which requires that entry be coupled with a specific intent to interfere or obstruct. See People v. Poe, 236 A.C.A. Supp. 722, 731, 47 Cal. Rptr. 670, 675 (1965).

50 Cf. Giaccio v. Pennsylvania, 382 U.S. 399 (1966).

57 See text accompanying notes 25-29 supra.

58 Compare the uncertainty of the term "gangster" in Lanzetta v. New Jersey, 306 U.S. 451 (1939). 
tory purposes. ${ }^{59}$ While the courts are reluctant to invalidate a legislative classification scheme, for example of economic regulation, if any distinctions may be found between those activities subject to and those excluded by the statute, ${ }^{60}$ the validity of the classification must clearly appear when a fundamental right is involved. ${ }^{61}$

Students, officers, and employees are exernpted. Arguably they, as well as outsiders, can contribute to the evil the statute seeks to prevent. Only some educational property is subject to the statute: Junior colleges are not included, and other public schools may become affirmatively obliged to open their doors to outsiders under the Civic Center Act. ${ }^{\text {22 }}$

The legislature is, however, generally allowed wide discretion to attack only part rather than all of the manifestations of the evils apprehended. ${ }^{03}$ Scrutiny would center more on the categories of persons exempted ${ }^{64}$ than on the types of property to which the statute apphes.

A more pervasive equal protection challenge to the administration of the statute would be available if it were applied to discriminate among users of University facilities. If one's affihation or the controversial nature of his opinions is the basis of denying to a person the use of facilities granted either by invitation or informal practice to more conventional speakers, then the equal protection guarantee acts to assure access. ${ }^{\text {of }}$

59 See Yick Wo v. Hopkins, 118 U.S. 356 (1886). See generally Tussman \& tenBrock, The Equal Protection of the Laws, 37 CALIF. L. REv. 341 (1949). Independent provisions of the California constitution provide a guarantee of equal protection. CAx. ConsT. art. I, $\$ \& 11$, 21. They have been held to apply whether or not the federal constitutional guarantee is operative. Department of Mental Hygiene v. Kirchner, 62 Cal. 2d 586, 400 P.2d 321, 43 Cal. Rptr. 329 (1965).

00 See, e.g., Ferguson v. Skrupa, 372 U.S. 726, 732 (1963); Williamson v. Lee Optical, Inc., 348 U.S. 483, 488-89 (1955); cf. Morey v. Doud, 354 U.S. 457 (1957).

61 Skinner v. Oklahoma, 316 U.S. 535, 541 (1942); Canon v. Justice Court, 61 Cal. 2d 446, 461, 393 P.2d 428, 436-37, 39 Cal. Rptr. 228, 236-37 (1964); see Katzev v. County of Los Angeles, 52 Cal. 2d 360, 341 P.2d 310 (1959). See also Schneider v. State, 308 U.S. 147 (1939).

02 Car. EdUC. Code $\$ \S 16551-56$.

63 See, e.g., McGowan v. Maryland, 336 U.S. 420, 425-26 (1961); Railway Express Agency, Inc. v. New York, 336 U.S. 106, 110 (1949); Miller v. Wilson, 236 U.S. 373, 384 (1915); McLean v. Arkansas, 211 U.S. 539, 552 (1909). For a discussion of statutory underinclusiveness as a denial of equal protection, see Comment, Aspects of Pay Television: Regulation, Constitutional Law, Antitrust, 53 CALI. L. REv. 1378, 1409-18 (1965).

${ }^{64}$ Cf. Mctaughlin v. Florida, 379 U.S. 184 (1964); Morey v. Doud, 354 U.S. 457 (1957).

65 Fowler v. Rhode Island, 345 U.S. 67 (1953); Niemotko v. Maryland, 340 U.S. 268 (1951); Buckley v. Meng, 35 Misc. 2d 467, 230 N.Y.S.2d 924 (Sup. Ct. 1962); People v. Amdur, 123 Cal. App. 2d Supp. 951, 971, 267 P.2d 445, 454 (1954); Van Alstyne, Political Speakers at State Universities: Some Constitutional Considerations, 111 U. PA. L. REv, 328, 338 (1963). See also Danskin v. San Dicgo Unified School Dist., 28 Cal. 2d 536, 171 P.2d 885 (1946) (equality of access based on first amendment rather than equal protection).

Present policies of the University of California permit only registered student organiza- 
Since state universities presently have a practice of inviting or permitting at least some outside speakers, ${ }^{66}$ this equal protection argunient is a strong potential challenge, although a defendant would be faced with difficult problems of proof.

Finally, one nust consider the potential for expansion of the equal protection clause revealed by recent decisions in the field of criminal procedure which impose an affirmative obligation on the state to rectify inbalances in treatnient which are not even of its own creation. ${ }^{67}$ If reasons of poverty or the unpopularity of their views prevent speakers from otherwise obtaining facilities for speech or assembly, conceivably an affirmative obligation might be imposed upon state agencies to provide such facilities. To say that the state may be obligated to provide speaking areas, however, is not to conclude that state college or university premises in particular are necessarily included among those areas. Part $\mathrm{V}$ of this Comment will examine this issue more closely.

\section{The First Amendment}

Serious constitutional challenges to section 602.7 arise from a number of related and overlapping doctrines designed to protect the values of free expression, association, and assembly as they are expressed in the first amendment. ${ }^{68}$ Penal Code section 602.7 arguably (1) offends the vagne-

tions to invite non-University speakers to address meetings on campuses. Prior notification to the administration is required, and the Chancellor may deny use of available facilities if he "deems the meeting to be incompatible with the educational objectives of the University." University of California, supra note 27 , at $\S \Pi(B)(c)(1)$. The Chancellor is responsible for assuring the opportunity for the expression of a variety of viewpoints over a period of time. Id. at $\S \Pi(\mathrm{B})(\mathrm{c})(3)$.

00 On the Chancellor's responsibility to assure representation of a variety of viewpoints, see note 65 supra.

07 See Douglas v. Cahfornia, 372 U.S. 353 (1963); Griffin v. Tllinois, 351 U.S. 12 (1956); cf. Jackson v. Pasadena School Dist., 59 Cal. 2d 876, 382 P.2d 878, 31 Cal. Rptr. 606 (1963); Balaban v. Rubin, 14 N.Y.2d 193, 250 N.Y.S.2d 281, 199 N.E.2d 375, cert. denied, 379 U.S. 881 (1964). Is this an independent interest justifying discriminatory treatment of speakers because the speaker represents a point of view that has recently and regularly been presented on campus?

08 Constitutional standards governing freedom of speech under the first amendment are applicable to a state agency under the fourteenth amendment. Smith v. California, 361 U.S. 147 (1959); Sweezy v. New Hampshire, 354 U.S. 234 (1957); Wollam v. City of Palm Springs, 59 Cal. 2d 276, 280 n.4, 379 P.2d 481, 483 n.4, 29 Cal. Rptr. 1, 3 n.4 (1963). Fourteenth amendment standards have been specifically applied to state universities and educational agencies in cases arising under the equal protection clause. Cooper v. Aaron, 358 U.S. 1 (1958); McLaurin v. Oklahoma State Regents, 339 U.S. 637 (1950). The comparable sections of the state constitution provide an independent guarantee of freedoin of speech and assembly. Car. Const. art. I, § 9. Cases commonly consider state and federal claims together. See, e.g., Canon v. Justice Court, 61 Cal. 2d 446, 393 P.2d 428, 39 Cal. Rptr. 228 (1964); Katzev v. County of Los Angeles, 52 Cal. 2d 360, 341 P.2d 310 (1959); Hirsch v. City \& County of San Francisco, 143 Cal. App. 2d 313, 300 P.2d 177 (1956). 
ness doctrine; (2) improperly delegates discretionary power to license speech and speech related activities; and (3) even were the power properly delegated, fails to provide sufficiently rigorous standards for exercising the power.

\section{The Vagueness Doctrine}

The vice of vagueness in a first amendment context $t^{00}$ is not only that a person is not given fair notice that his activity is wrongful, nor solely that a statute might permit arrest and even conviction of a person for his having refused to desist from a form of constitutionally protected expression, but primarily that the existence of vague penal statutes deters the exercise of protected expression. ${ }^{70}$ The fear that rights will be restricted sub silentio by overbroad or vague statutes has led courts to depart from the general rule ${ }^{71}$ that one may not question the constitutionality of a provision as it may be apphied to others, and to consider possible fact situations other than that before it. ${ }^{72}$ Arguably, therefore, even one whose conduct is regulable under a statute drawn with requi-

60 See Aptheker v. Secretary of State, 378 U.S. 500, 516 (1964): "Since this case involves a personal liberty protected by the Bill of Rights, we believe that the proper approach must be that adopted by this court in NAACP v. Button, 371 U.S. 415 . . . 'The objectionable quality of vagueness and overbreadth does not depend upon absence of fair notice to a criminally accused, or upon unchanneled delegation of legislative powers, but upon the danger of tolerating, in the area of First Amendment freedoms, the existence of a penal statute susceptible of sweeping and improper application .... The threat of sanctions may deter their exercise almost as potently as the actual application of sanctions.' "Both Collings and Amsterdam note the different treatment of the vagueness doctrine in speech and nonspeech contexts. See Collings, supra note 52, at 218-19; Amsterdam, supra note 52 , at 75 .

For a similar distinction in California, compare Fort v. Civil Serv. Comm'n, $61 \mathrm{Cal}$. 2d 341, 392 P.2d 391, 38 Cal. Rptr. 631 (1964) (abridgment of civil servant's rights of free speech), with People v. Victor, 62 Cal. 2d 280, 398 P.2d 391, 42 Cal. Rptr. 199 (1965) (police power to commit one "in imminent danger of becoming addicted"); In re Huddleson, 229 Cal. App. 2d 618, 40 Cal. Rptr. 581 (1964).

${ }^{70}$ See opinion of Brennan, J., in Smith v. California, 361 U.S. 147, 151 (1959): "[T]his court has intimated that stricter standards of permissible statutory vagueness may be applied to a statute having a potentially inhibiting effect on speech; a man may the less be required to act at his peril here, because the free dissemination of ideas may be the loser."

While vagueness in other areas may be cured by construction, a statute which in general terms infringes on the constitutional right of free speech may be struck down in its entirety. In re Blaney, 30 Cal. 2d 643, 653-56, 184 P.2d 892, 899-901 (1947). See also NAACP v. Button, 371 U.S. 415, 433 (1963); Winters v. New York, 333 U.S. 507 (1948); Herndon v. Lowry, 301 U.S. 242 (1937); Stromberg v. California, 283 U.S. 359 (1931).

71 United States v. Raines, 362 U.S. 17, 21-22 (1959); In re Cregler, 56 Cal. 2d 308, 313, 363 P.2d 305, 308, 14 Cal. Rptr. 289, 292 (1961).

72 See NAACP v. Button, 371 U.S. 415, 432-33 (1963); Cramp v. Board of Pub. Instruction, 368 U.S. 278 (1961); Thornhill v. Alabama, 310 U.S. 88, 96-99 (1940); Fort v. Civil Serv. Comm'n, 61 Cal. 2d 331, 339, 392 P.2d 385, 390, 38 Cal. Rptr. 625, 630 (1964). See discussion comparing and distinguishing vagueness and overbreadth, note 77 infra. 
site narrow specificity might have standing to raise the constitutional defense. $^{73}$

In the recent cases of Cox $v$. Louisiana, ${ }^{74}$ problems of vagueness, delegation, and absence of proper standards are closely intertwined, but the cases do help illustrate the distinction between the impermissibly vague statute and one drawn with the requisite clarity. In Cox I a statute permitting conviction for "congregating with others with intent to provoke a breach of the peace, or under circumstances such that a breach of the peace may be occasioned"75 was, as interpreted by the Louisiana court, ${ }^{76}$ held to be "unconstitutionally vague in its overly broad scope" since it permitted punishment for peaceful expression of unpopular views. ${ }^{78}$ In Cox II a statute prohibiting picketing "near" a courthouse was found to be sufficiently specific so as not to permit infringement of speech guarantees.

Under Penal Code section 602.7, the act likely to interfere with peaceful conduct could be an act of speech, association, or assenubly. ${ }^{79}$ The

${ }^{73}$ See Dombrowski v. Pfister, 380 U.S, 479 (1965) (statutory overbreadth). See also dissent of Wisdom, J., in Dombrowski v. Pfister, 227 F. Supp. 556, 569 (1964), rev'd, 380 U.S. 479 (1965).

74379 U.S. 536 (1965); 379 U.S. 559 (1965) [hereinafter referred to as Cox $I$ and Cox II].

75 LA. REv. Stat. \& 14:103.1 (Supp. 1962).

70 State v. Cox, 244 La. 1087, 1105, 156 So. 2d 448, 455 (1963).

$77379 \mathrm{U}$.S. at 551 . Vagueness is presumably an aspect of overbreadth, since the danger to or deterrence of protected expression arises from the lack of clarity in the statutory line demarcating proscribed from protected conduct. A statute might not, however, be vague, in the sense that it clearly demareates the proscribable conduct, and yet still be overbroad because the classification clearly made permits punishment of constitutionally protected activity.

78 Feiner v. New York, 340 U.S. 315 (1951), which had upheld the conviction of a street corner speaker based upon the threatening reaction by his audience, was distinguished, as in Edwards v. South Carolina, 372 U.S. 229 (1963), on the absence of threatened violence. 379 U.S. at 551; cf. Shuttlesworth v. City of Birmingham, 382 U.S. 87 (1965).

Cox $I$ and Edwards seem to have revived Terminiello v. Chicago, 337 U.S. 1 (1949), which reversed a conviction based upon a fact situation substantially similar to that in Feiner, which, after Feiner, had seemed quiescent. While Feiner was distinguished in both Cox $I$ and Edwards, the latter cases might also be taken to suggest at least some obligation upon the police to proceed, if possible, against the hostile audience before attempting to curtail those engaged in acts of speech or assembly which are not deliberate incitements to riot. The latter was the position of Justice Black, dissenting in Feiner. 340 U.S. at 326 (citing Terminiello); cf. Sellers v. Johnson, 163 F.2d 877 (8th Cir. 1947), cert. denied, 332 U.S. 851 (1948). See also Note, Freedom of Speech and Assembly: the Problem of the Hostile Audience, 49 Colusr. L. Rev. 1118, 1123-24 (1949).

70 See text accompanying note 37 supra. Courts often will not reach constitutional questions if their decision can reasonably be avoided by a clarifying or limiting construction of a statute. Peters v. Hobby, 349 U.S. 331, 338 (1955); United States v. Rumely, 345 U.S. 41, 45 (1953); Charles River Bridge v. Warren Bridge, 36 U.S. (11 Pet.) 420, 553 (1837); County of Madera v. Gendron, 59 Cal. 2d 798, 801, 382 P.2d 342, 344, 31 Cal. Rptr. 302, 304 
statute does not state how serious must be the interference, how great must be the likelihood of its occurrence, whether the interference must be by a speaker or by his audience, ${ }^{80}$ nor whether the interference could be caused by the content of the speech, or only by some aspect relating to the time, place, and manner in which it is delivered.

In addition to the vagueness of the phrases "any act," "likely to interfere," and "peaceful conduct," section 602.7 arguably superimposes upon the vagueness of the standard of proscribable conduct a second level of vagueness, since the condition under which the delegated power is to be exercised itself partakes of vagueness. It need only "reasonably appear" to the official that the conditions are met-a standard more subjective than that of probable cause ${ }^{81}$ since the latter has acquired through judicial decision an objective cast involving external standards of verifiability.

$A d$ hoc judgments by the official are required to determine what is "peaceful conduct" and what constitutes the "likelihood of interference" with it. These latter phrases demand appeals to judgment or require the resolution of questions of degree in each particular situation in a way which no judicial gloss on a vague statute can clarify. ${ }^{82}$ Statutes employing phrases of this character have been treated differently, ${ }^{83}$ but do receive close judicial scrutiny in first amendment cases involving ad hoc sub-

(1963); American Civil Liberties Union v. Board of Educ., 59 Cal. 2d 203, 218, 379 P.2d 4, 12-13, 28 Cal. Rptr. 700, 708-09 (1963) ; People v. Amdur, 123 Cal. App. 2d Supp. 951, 961, 267 P.2d 445, 451 (1954). If a court should construe the word "act" to exclude types of conduct protected under the first amendment, many of the constitutional challenges might be avoided. Cf. Canon v. Justice Court, 61 Cal. 2d 446, 393 P.2d 428, 39 Cal. Rptr. 228 (1964).

80 See text accompanying notes 102-14 infra.

$81 \mathrm{It}$ has been argued that this standard enshrines the objective reasonable man test. Opinion of Legislative Counsel No. 17766 (April 30, 1965), reprinted in AssearbLX DAntx JOURNAL 3443-48 (May 17, 1965). This view may not take into account the generally stricter standards in cases involving constitutionally protected freedoms. See, e.g., Buckley v. Meng, 35 Misc. 2d 467, 230 N.Y.S.2d 924, 930 (Sup. Ct. 1962) ("As long as it is possible for reasonable men to differ as to what a given standard means, that standard cannot properly serve as a basis for a limitation on First Amendment rights."). The Supreme Court has struck down cases on vagueness grounds where reasonableness was part of the statutory standard. See, e.g., Cline v. Frink Dairy Co., 274 U.S. 445 (1927) (unreasonable profits); United States v. L. Cohen Grocery Co., 255 U.S. 81 (1921) (unreasonable rates). Sec generally Amsterdam, supra note 52, at 93.

82 Professor Freund has distinguished three grades of certainty in the language of statutes: (1) precisely measured terms, (2) abstractions of common certainty, and (3) ternns involving an appeal to judgment or a question of degree. Freund, The Use of Indefinite Terms in Statutes, 30 YAIE L.J. 437 (1921). Vagueness cases most often deal with statutory language of the third type. Phrases of this type have aptly been terned "phrases of inherent discontrol." Amsterdam, supra note 52, at 93.

83 Compare Winters v. People of New York, 333 U.S. 507 (1948); Herndon v. Lowry, 301 U.S. 242 (1937); Joseph Burstyn, Inc. v. Wilson, 343 U.S. 495 (1952), with Boyce Motor Lines, Inc. v. United States, 342 U.S. 337 (1952); United States v. Petrillo, 332 U.S. 1 (1947) ; Umited States v. Ragan, 314 U.S. 513 (1941) ; Baltimore \& Ohio R.R. v. Groeger, 266 U.S. 521 (1925). 
jective evaluation of conduct, or the exercise of discretion to license various forms of public expression. ${ }^{84}$

The deterrent nature of a vague penal statute such as Penal Code section 602.7 is evident. For those wlo violate the order there is at least the opportunity to litigate the constitutional claim in a criminal proceeding ${ }^{85}$ for those wlio obey the officer's order there would appear at best to be only the uncertain redress of a civil suit after the time when the intended expression miglit have had its maximum or even its only effectiveness.

\section{Delegation of Licensing Power}

Power to permit or refuse access to public places must be delegated in a manner which does not give a subordinate official the untramineled discretion to choose which types of conduct or which ideas shall be accorded hospitality.$^{86}$ Section 602.7 arguably fails to provide these required standards, and therefore vests a discretionary power to "license" speech and speech related activities. To the extent that an officer can order to leave someone who reasonably appears to have entered for the purpose of committing an act likely to interfere, before that as yet unidentified act can be assessed for its disruptive potential, there exists a system of prior restraints. ${ }^{87}$ Any system having this kind of effect, whatever its form, inust overcome a strong presumption of invalidity: ${ }^{88}$ The existence of

84 See Staub v. City of Baxley, 355 U.S. 313 (1958); Superior Films, Inc. v. Department of Educ., 346 U.S. 587 (1954); Gelling v. Texas, 343 U.S. 960 (1952); Niemotko v. Maryland, 340 U.S. 268 (1951); Cantwell v. Connecticut, 310 U.S. 296, 305 (1940).

85 If the scope of review is only of the "reasonableness" of the exercise of administrative discretion, or the reasonableness of an indirect regulation of speech, even this opportunity for review would be circumscribed. See Umited States v. Harriss, 347 U.S. 612, 626 (1954); American Communications Ass'n v. Douds, 339 U.S. 382, 390-99 (1950); Cox v. New Hampshire, 312 U.S. 569, 578 (1941); American Civil Liberties Umion v. Board of Educ., 59 Cal. 2d 203, 213, 379 P.2d 4, 9, 28 Cal. Rptr. 700, 705, cert. denied, 375 U.S. 823 (1963). Whether the regulation of speech in $\S 602.7 \mathrm{can}$ be said to be indirect is at best questionable since the broad wording allows direct termination of whatever act or intended act is deened likely to interfere, and hence would seem to allow the direct imposition of prior restraints on speech-type activities. See generally Blease, The Civic Center Act and the Freedom of Speech, 2 LAW CoMarentary 43 (1964).

86 Cox v. Louisiana, 379 U.S. 536, 557 (1965); Kunz v. New York, 340 U.S. 290 (1951); Nienrotko v. Maryland, 340 U.S. 268 (1951); Saia v. New York, 334 U.S. 558 (1948); Largent v. Texas, 318 U.S. 418 (1943).; Cantwell v. Connecticut, 310 U.S. 296 (1940); Schneider v. State, 308 U.S. 147 (1939); Hague v. CIO, 307 U.S. 496 (1939); Lovell v. Griffin, 303 U.S. 444 (1938).

87 See generally Emerson, The Doctrine of Prior Restraint, 20 LAW \& Contranp. Prob. 648 (1955); Note, Prior Restraint-A Test of Invalidity in Free Speech Cases?, 49 Condr. L. Rev. 1001 (1949).

88 Bantam Books, Inc. v. Sullivan, 372 U.S. 58 (1963) ; Staub v. Baxley, 355 U.S. 313, 321 (1958); Kunz v. New York, 340 U.S. 290, 293 (1951); Niemotko v. Maryland, 340 U.S. 268, 273 (1951); Cantwell v. Connecticut, 310 U.S. 266, 306 (1940); Schneider v. 
a discretionary potential to initiate the punitive process against one who engages in arguably protected activity deters the exercise of protected rights.

In Cox $I$ the Supreme Court refused to distinguish between the type of statute expressly providing that there could be peaceful parades only in the unbridled discretion of local officials, and a broad prohibitory statute expressly permitting selective enforcement which would enable a state or mumicipality to determine which expressions or views can be permitted: Either system would constitute a device for the suppression of ideas, ${ }^{89}$ and a potential denial of equal protection. Discretionary systems to determine which ideas will be permitted lave similarly been invalidated when applied specifically against prospective speakers seeking access to public school buildings. ${ }^{90}$

A hicensing scheme may not give an official discretion to regulate the content of the ideas presented, although it may give narrow discretion to make determinations concerning the time, place, duration, and manner of demonstrations. ${ }^{91}$ As Part II of this Cominent has indicated, the failure of section 602.7 to specify the manner or type of disruption, or by whom it must be caused, results in a broad power to curtail activities that may be constitutionally protected. Since the official is not required to eject a person who is committing any proscribable act, section 602.7 would seem to be that type of broad prohibitory statute permitting selective enforcement which the Supreme Court invalidated in Cox $I$, and is perhaps even more deficient than the statute in $\operatorname{Cox} I$, since the discretionary power to impose prior restraint is express in section $602.7 .^{92}$

State, 308 U.S. 147, 164 (1939); Lovell v. Griffin, 303 U.S. 444 (1938); Near v. Minnesota, 283 U.S. 697 (1931).

89379 U.S. at 557 . Perhaps courts will be reluctant to extend the full force of decisions in the civil rights area to other types of activity. Even Cox $I$ seems to question the extent to which conduct other than pure speech is to be protected. For a discussion criticizing this aspect of the decision, see Kalven, The Concept of the Public Fortm: Cox v. Lonisiana, in 1965 SUPREME CoURT REv. 1, 23 (Kurland ed. 1965). Whatever be the borderline between the unprotected speech of Chaplinsky v. New Hampshire, 315 U.S. 568 (1942) ("fighting words"); Beauharnais v. Illinois, 343 U.S. 250 (1952) (group libel); and Feiner v. New York, 340 U.S. 315 (1951), on one hand; and that protected in Terminiello v. Chicago, 337 U.S. 1 (1949); Edwards v. South Carolina, 372 U.S. 229 (1963); Cox I on the other, the validity of $\S 602.7$ would not seem to depend on the delineation of the penumbra, since some conduct embraced by $\S 602.7$ appears to be clearly protected. Cf. Brown v. Louisiana, 86 Sup. Ct. 719 (1966).

In addition, the force of the vagueness rationale and the critique of administrative licensing schemes rests less on the substantive limits of first amendment protection than on the nature of the system by which exercise of expression is controlled or deterred.

${ }^{90}$ See cases cited at notes 170,171 infra.

91 Cox v. Louisiana, 379 U.S. 559, 569 (1965); Poulos v. New Hampshire, 345 U.S. 395 (1953); Cox v. New Hampshire, 312 U.S. 569 (1941); of. Saia v. New York, 334 U.S. 558 (1948).

${ }^{92}$ In Cox II, the Court specifically noted that the on-the-spot discretion to construe 
The particular method by which a determination as to the protected nature of a form of expression is both made and reviewed is also important in assessing the adequacy of a delegation of licensing power. The Supreme Court has recently held unconstitutional several atteinpts to proscribe activities arguably involving elements of protected expression because the safeguards of the criminal process were by-passed through delegation of decision-making powers to nonjudicial bodies. ${ }^{93}$ In Bantam Books, Inc. v. Sullivan, ${ }^{94}$ the Supreme Court held as an unconstitutional prior restraint the activities of a Rhode Island commission engaged in informal censorship of literature and other forms of expression. The practice of the board had been to notify sellers that particular material was found objectionable, to request their cooperation, and to advise them that police and prosecutors received copies of hists of objectionable material. It was found that the notices were phrased virtually as orders and were followed by police visitations to view comphance with the suggested suppression. The vice of the Rhode Island system was held to be the superimposition of an effective form of state regulation upon the state's criminal regulation of obscenity, inaking the latter largely unnecessary. In obviating the need to employ criminal sanctions, the state at the same time eliminated the safeguards of the criminal process, since criminal sanctions may only be applied after a determination of obscenity has been made in a criminal trial hedged about with the procedural safeguards of the criminal process. ${ }^{95}$

The parallel of section 602.7 to the Bantam Books rationale is significant in this respect: Conduct nay be circumscribed by an adminis-

the term "near" which was given by the statute to the administrative official was limited to a specific type of conduct in a few specified areas in the immediate vicinity of the courthouse and was thus of the type of narrow discretion to determine proper time, place, duration, and manner of protected speech-related activities which the court had recognized as the function of responsible officials. The statute was not found to confer that unbridled discretion which would allow an official to pick and choose among expressions or views the ones he would permit to be promulgated on the public streets as had the statute the Court had invalidated in the obstructing-the-public-passages conviction in Cox I. 379 U.S. at 569. This holding may represent a turning away from the 1964 sit-in cases, see note 3 supra and Edwards v. Soutl Carolina, 372 U.S. 229 (1963), where the Court appeared to assimilate picketing and parading more closely to speech. Then too, Cox II may be read in light of the judicial sensitivity to special needs of the judicial process. Cf. Estes v. Texas, 381 U.S. 532 (1965). In so far as an "act" under $\$ 602.7$ would include speech in its pristine form, even Cox II's speech-nonspeech distinction does not remove the statute from constitutional doubts.

93 "Delegation" in this context is different than delegation of legislative power to administrative officials under vague or indefinite standards, even when penal sanctions are involved. Few recent cases have held such a delegation unlawful. See generally 2 Davis, administrative Law Treatise ch. 2 (1958).

94372 U.S. 58 (1963).

95 Id. at 69-70; accord, Zeitlin v. Arnebergh, 59 Cal. 2d 901, 383 P.2d 152, 31 Cal. Rptr. 800 , cert. denied, 375 U.S. 957 (1963). 
trative determination which, if acquiesced in, precludes a judicial determination of whether the conduct intended or committed constitutes a protected form of expression. Bantam Books suggests that a censorship system imposing prior restraints will be tolerated only under judicial superintendence where the validity of the restraint receives an almost immediate determination.

A later obscenity decision, Freedman v. Maryland ${ }^{90}$ specifically cited the principal speech cases involving overly broad delegations of "licensing" discretion to an administrative official as authority for allowing one who had intentionally refused to seek a required permit to attack the whole censorship scheme. ${ }^{97}$ No distinction was made between prior restraints in obscenity determinations and prior restraints in other speech contexts..$^{98}$ Freedman elaborated more specifically the kind of judicial superintendence which would be required in a proper censorship system.99 It indicated that the censor must bear the burden of establishing the unprotected nature of the expression, that the censor's determination must not be final, and that the procedure must assure prompt final judicial determination.

The Bantam Books and Freedman considerations seem particularly applicable to the case of one whose speech-type conduct could be terminated by his obedience to a request to depart given under Penal Code section 602.7. Unlike a direct prosecution for breach of the peace, or for obscenity, censorship by a noncriminal process puts the initial burden of establishing the protected nature of the expression on the person who would exercise it; his stake in any one venture may be insufficient to warrant protracted and onerous litigation. The deterrent effect of such procedures on protected material is one reason for their unconstitutionality. ${ }^{100}$ The constitutional issue is not merely whether a person is prosecuted, or whether protected rights are actually infringed in a given case, but also whether the administrative censorship scheme will by its existence and

98380 U.S. 51 (1965).

97 Id. at 56. Motion pictures may be subject to different, more stringent rules of censorship. See Times Film Corp. v. Chicago, 365 U.S. 43 (1961); Joseph Burstyn, Inc. v. Wilson, 343 U.S. 495, 503 (1952). But see Freedman v. Maryland, 380 U.S. 51 (1965) (Douglas, J., concurring).

${ }^{98}$ See also Marcus v. Search Warrants of Property, 367 U.S. 717 (1961), where ad hoc administrative determinations of obscenity made while executing a search warrant were held invalid. The procedure gave no opportunity for discriminating deliberation which could focus searchingly on the question of the obscenity of the seized materials. The Court also noted the absence of opportunity to contest the seizing officer's belief that the material was "obscene," or to argue against the propriety of the seizure to the issuing judge. Id. at 731 . Such opportumities are also lacking in \$602.7.

99 See Kingsley Books, Inc. v. Brown, 354 U.S. 436 (1957), referred to as a "model" in Freedman, 380 U.S. at 60. See also Comment, 51 CaLIF. L. Rev. 620 (1963).

100 See Freedman v. Maryland, 380 U.S. 51 (1965). 
the manner in which it makes determinations deter full assertion of the right to free expression. ${ }^{101}$

\section{Breadth of Standards}

It has been suggested that an administrative official's action under a hicensing system might be upheld if there exist appropriate standards to guide his conduct. ${ }^{102} \operatorname{Cox} I$ and $I I$, however, and Edwards v. South Carolina $a^{103}$ indicate that any administrative licensing scheme in the first amendment context is invalid unless restricted to narrow considerations of time, place, and manner. Related "prior restraint" cases point to the necessity of effective judicial review of administrative decisions if the determination as to the protected nature of a form of expression has bypassed the procedural safeguards of the criminal process.

Even assuming that the standards of section 602.7 were not found unconstitutionally vague, and that the statute did not create discretionary licensing power in the administrative official, it would nonetheless seem to be invalid on its face for overbreadth. The standards permitting ejection for acts likely to interfere with the peaceful conduct of a campus or facility would, as apphed to speech-type activity, appear less stringent than those demanded by the "clear and present danger standard,"104 and by such cases as Terminiello v. Chicago, ${ }^{105}$ Edwards v. South Carolina, ${ }^{106}$

101 See Thornhill v. Alabama, 310 U.S. 88, 97 (1940) ("It is not merely the sporadic abuse of power by the censor but the pervasive threat inherent in its very existence that constitutes the danger to freedom of discussion."); accord, Danskin v. San Diego Unified School Dist., 28 Cal. 2d 536, 551, 171 P.2d 885, 894-95 (1946).

102 Kunz v. New York, 340 U.S. 290, 295 (1951) (dictum).

103372 U.S. 229 (1963).

104 Direct restrictions on speech or assembly have been held invalid unless they meet the rigid standards of this test. See Schenck v. United States, 249 U.S. 47, 52 (1919); accord, Martin v. Struthers, 319 U.S. 141 (1943) (ordinance prohibiting distribution of handbills to homes); Thornhill v. Alabama, 310 U.S. 88 (1940) (prohibition of peaceful picketing); De Jonge v. Oregon, 299 U.S. 353 (1937) (criminal syndicalism statute outlawing peaceful Communist Party meetings); American Civil Liberties Union v. Board of Educ., 55 Cal. 2d 167, 359 P.2d 45, 10 Cal. Rptr. 647 (1961); Danskin v. San Diego Unified School Dist., 28 Cal. 2d 536, 171 P.2d 885 (1946).

Dennis v. Umited States, 341 U.S. 494 (1951), has modified the test to the extent that a probahility of a grave evil ohviates the necessity to prove the danger imminent. See Van Alstyne, Political Speakers at State Universities: Some Constitutional Considerations, 111 U. PA. L. REv. 328, 333 (1963). Despite the Dennis modification, California courts have continued to require the showing of a grave and immediate danger to an interest which the state has a right to prevent, and to demand a showing of a close causal connection between the substantive evil and the method chosen to deal with it. See Katzev v. County of Los Angeles, 52 Cal. 2d 360, 365-67, 341 P.2d 310, 314-15 (1959) (violation of both federal and Cahfornia constitutional guarantees); Weaver v. Jordan, 64 A.C. 243 (1966); Note, 48 CALIF. L. REv. 145 (1960).

105337 U.S. 1 (1949).

106372 U.S. 229 (1963). 
and Cox $I^{107}$ In Terminiello conviction for breach of the peace was reversed because the jury instruction permitted conviction where the speech "stirred people to anger, invited public dispute, or brought about a condition of unrest." 108 Speech is protected, the Court said, "unless shown likely to produce a clear and present danger of a serious substantive evil that rises far above public inconvenience, annoyance or unrest." "109

In $\operatorname{Cox} I$ the Court concluded after independent examination of the record ${ }^{110}$ that conduct of appellants did not differ significantly from that held to be protected in Edveards v. South Carolina and that even though anticipated violent crowd reaction to the peaceful expression of unpopular views miglit have necessitated police protection, that expression could not constitute a breacli of the peace. ${ }^{111}$

The standard given by section 602.7 is not limited by its terms ${ }^{112}$ to regulations of time, place, and nnanner of speech-related activities, but may be applied to the content of speech itself, and could permit curtailinent of a speech where interference with the peaceful conduct of the campus arises from audience reaction rather than from any intentional incitement by the speaker. The possibility of direct censorship of the content of speech is apparent, ${ }^{113}$ particularly since the standard itselfmere likelihood of an interference of unspecified severity-falls short of setting down clear and present danger guidelines. ${ }^{114}$

If an individual goes upon a campus to speak, then officials should not, under the established doctrines, demand that he desist unless they can show that the speaker is seriously threatening some substantial interest of the university. The terms of section 602.7 do not so specify.

107379 U.S. 536 (1965).

108337 U.S. at 5.

$109 \mathrm{Id}$. at 4. In the analogous race relations context, the Supreme Court has reversed convictions for breach of the peace where peaceful activity has led to acts by hostile onlookers. See, e.g., Barr v. City of Columbia, 378 U.S. 146, 150 (1964); Henry v. City of Rock Hill, 376 U.S. 776 (1964); Wright v. Georgia, 373 U.S. 284 (1963); Edwards v. South Carolina, 372 U.S. 229 (1963); Taylor v. Louisiana, 370 U.S. 154 (1962); Garner v. Louisiana, 368 U.S. 157 (1961).

$110 \mathrm{~A}$ Supreme Court prerogative in cases involving claims of constitutional right. Haynes v. Washington, 373 U.S. 503, 515, 516 (1963); Edwards v. South Carolina, 372 U.S. 229 (1963); Blackburn v. Alabama, 361 U.S. 199, 205 (1960); Pennekainp v. Florida, 328 U.S. 331, 335 (1946); Fiske v. Kansas, 274 U.S. 380, 385, 386 (1927).

$111 C f$. Shuttlesworth v. City of Birmingham, 382 U.S. 87 (1965).

112 The possibility of a judicial gloss to restrict an overbroad statutory standard still remains. See, e.g., In re Huddleson, 229 Cal. App. 2d 618, 40 Cal. Rptr. 581 (1964).

$113 \mathrm{Cf}$. Niemotko v. Maryland, 340 U.S. 268 (1951); Saia v. New York, 334 U.S. 558, 562 (1948) ("annoyance at ideas ctn be cloaked in annoyance at sound").

114 See note 104 supra; cf. Bridges v. California, 314 U.S. 252, 262 (1941): "Moreover, the likelihood, however great, that a substantive evil will result cannot alone justify a restriction upon freedom of speech or the press. The evil itself must be 'substantial'. ..." 
Thus even assuming the statute not to be unconstitutionally vague, the delegation to be proper, and the statute not overbroad on its face, still, any defendant in a section 602.7 prosecution should be afforded the opportunity to escape conviction by showing his speech or conduct to be less threatening to the countervailing interests sought to be protected than was that in Terminiello, Edwards, and Cox $I$, and therefore to be within the pale of constitutionally protected activity.

\section{V}

FROM TITLE TO Telos

What type of right to be on university property must the individual have to avail himself of constitutional guarantees of free expression? Does the university have a power, as might the private homeowner, to close off the canipus altogether to outsiders? Would any otherwise applicable constitutional objections to Penal Code section 602.7 be of no avail because outsiders have no "right" to be on the campus?

The Supreme Court has not exphcitly ruled on the obligation of a state or municipahty to open up, or the extent of its power to close off, areas suitable for public expression, ${ }^{115}$ nor have the cases suggested how closely the decisions of authorities to prohibit use of a particular area will be examined in the face of a claim by members of the public that the availability of the area is essential to the effective exercise of freedom of speech or assembly. Traditional analysis focuses primarily on the title holder's riglit to exclusive possession; more recently answers have been sought in the light of the purposes of those who seek to use the area or facility and the other public interests involved.

115 See Cox v. Louisiana, 379 U.S. 536, $555 \mathrm{n.13}$ (1965): "It has been argued that, in the exercise of its regulatory power over streets and other public facilities, a State or municipality could reserve the streets completely for traffic and other facilities for rest and relaxation of the citizenry. See Kovacs v. Cooper, ... [336 U.S.] at 98 (opinion of Mr. Justice Jackson); Kunz v. New York, ... [340 U.S.] at 298 (Mr. Justice Jackson, dissenting). The contrary, bowever, has been indicated, at least to the point that some open area must be preserved for outdoor assemblies. See Hague v. C.I.O., . . [307 U.S.] at 515-516 (opinion of Mr. Justice Roberts); Kunz v. New York, supra, at 293; Niemotko v. Maryland, .. . [340 U.S.] at 283 (Mr. Justice Frankfurter, concurring)." In earlier licensing cases, the right to be present was conceded. See, e.g., Cantwell v. Connecticut, 310 U.S. 296, 308 (1940) ("upon a public street, where be had a right to be"); Schneider v. State, 308 U.S. 147, 160 (1939) ("rightfully upon the street"). See also Edwards v. South Carolina, 372 U.S. 229, 236 (1963) (different case would be presented if it were a violation of laws himiting periods state grounds may be open to the public); Schneider v. State, supra (private property trespasses may be forbidden).

In People v. Martin, 43 Misc. 2d 355, 251 N.Y.S.2d 66 (Sup. Ct. 1964), where a disorderly conduct conviction for refusal to leave a public school building was affirmed, the court distinguished Edwards and related cases on the ground that in those cases state laws had not forbidden the demonstrators to be present at the place of their protest. But of. Brown v. Louisiana, 86 Sup. Ct. 719 (1966). 


\section{A. The Title Analysis ${ }^{118}$}

The argument that title held by a state or municipality to particular public property conclusively establishes the right to exclude all or some members of the public on whatever basis is chosen is most clearly expressed in the 1897 case of Davis v. Massachusetts. ${ }^{117}$ There the Supreme Court affirmed conviction of a speaker who had claimed that the Boston Common was the property of the inhabitants, and therefore had refused to obtain the required permit from the mayor. The Court, in affirming the opinion of Judge Holmes, ${ }^{118}$ then on the Massachusetts Court, reasoned as follows:

The assertion that although it be conceded that the power existed in the state or municipality to absolutely control the use of the common, the particular ordinance in question is nevertheless void because arbitrary and unreasonable in that it vests in the mayor the power to determine when he will grant a permit, il truth, whilst admitting on the one hand the power to control, on the other denies its existence. The right to absolutely exclude all right to use, necessarily includes the authority to determine under what circumstances such use may be availed of, as the greater power contains the lesser. ${ }^{110}$

The title rationale of Davis has increasingly been questioned, but it has never been overruled. ${ }^{120}$ Part IV has examined the inroads made on the "lesser" power to discrimmate among users of public property, to censor ideas, or to condition use upon the relinquishment of constitutionally protected speech and due process rights. ${ }^{121}$ Section 602.7 does

116 This and subsequent sections of this Comment draw heavily upon Linde, Constitutional Rights in the Public Sector: Justice Douglas on Liberty in the Welfare State, 40 WASH. L. REv. 10 (1965). See also Gould, Union Organizational Rights and the Concept of "Quasi-Public" Property, 49 MinN. L. Rev. 505 (1965).

117167 U.S. 43 (1897).

118 Commonwealth v. Davis, 162 Mass. 510, 39 N.E. 113 (1895).

110167 U.S. at 48.

129 The Davis case has been challenged, but avoided rather than overruled in two important cases. Fowler v. Rhode Island, 345 U.S. 67, 68-69 (1953); Hague v. CIO, 307 U.S. 496, 515 (1939). The "ownership" theory advanced in Davis seems to have been rejected in subsequent cases in favor of a recognition that the governmental interest at stake which justifies denial of access to public property is an adjunct of its regulatory power. See, e.g., Jamison v. Texas, 318 U.S. 413 (1943); Hague v. CIO, supra at 514-16 (1939). When the regulation impinges upon a protected right, the Court has at times imposed an "alternatives" test to prohibit infringements of freedoms where other legislative measures could have struck more narrowly at the evil. See Schneider v. State, 308 U.S. 147, 162 (1939); accord, Sherbert v. Verner, 374 U.S. 398, 407-08 (1963). See generally Wormuth \& Mirkin, The Doctrine of the Reasonable Alternative, 9 UTAB L. REv. 254, 267-93 (1964).

121 Cf. Danskin v. San Diego Unified School Dist., 28 Cal. 2d 536, 171 P.2d 885 (1946) (unconstitutionality of condition denying use of school building to "subversive elements"found to offend first amendment rather than equal protection clause). On unconstitutional conditions generally, see Hale, Unconstitutional Conditions and Constitutional Rights, 35 CoLUM. L. REv. 321 (1935); Linde, supra note 116; Merrill, Unconstitutional Conditions, 
not attempt to prohibit altogether access by outsiders: indeed, University of California rules implicitly recognize their presence. Consequently, the restrictions on use by outsiders would seem to be subject to constitutional limitations which apply to the use of any other public place. ${ }^{122}$ The "greater power" itself-the right of a state to seal off its college and university campuses by criminal trespass laws-is not so settled as the analogous situation with public parks appeared to Judge Holmes in 1895. But if the riglits of free speeclı and assembly, while fundaniental, "still do not mean that everyone with opinions and beliefs may address a group at any public place and at any time,"123 what are the proper guidelines for the use of public places?

\section{B. Title and Trespass}

The title analysis permits use of criminal trespass laws to punish a defendant's conduct without reference to the appropriateness of the interests at stake. ${ }^{124}$ It therefore obscures the real issue, whicll is the

77 U. PA. I. REv. 879 (1929); Willcox, Invasions of the First Amendment Through Conditioned Public Spending, 41 CoRNerr I.Q. 12 (1955); Note, Unconstitutional Conditions, 73 HARv. L. REv. 1595 (1960); Note, Judicial Acquiescence in the Forfeiture of Constitutional Rights Through Expansion of the Conditioned Privilege Doctrine, 28 IND. L.J. 520 (1953); cf. American Communications Ass'n v. Douds, 339 U.S. 382, 417 (1950) (separate opinion of Frankfurter, J.): "Congress may withhold all sorts of facilities for a better life but if it affords them it cannot make them available in an obviously arbitrary way or exact surrender of freedoms unrelated to the purpose of the facilities." For a general discussion of many of the Bill of Rights issues raised by the emergence of government as a major source of wealth, see Reich, The New Property, 73 YaLe L.J. 733 (1964).

122 See Sherbert v. Verner, 374 U.S. 398, 404 (1963): "It is too late in the day to doubt that the liberties of religion and expression may be infringed by the denial of or placing of conditions upon a benefit or privilege." Cf. Umited States v. Romano, 382 U.S. 136, 144 (1965): "1t may be, of course, that Congress has the power to make presence at an illegal still a punishable crime, but we find no clear indication that it intended to so exercise this power. The crime remains possession, not presence, and, with all due deference to the judgment of Congress, the former may not constitutionally be inferred from the latter." 123 Cox v. Louisiana, 379 U.S. 536, 554 (1965).

124 People v. Martinez, 43 Misc. 2d 94, 250 N.Y.S.2d 28 (N.Y. City Crim. Ct. 1964), noted in 16 Syracuse I. REv. 242 (1965), reflects the Davis approach. Defendants refused to leave a police station after liaving been denied permission to see the Police Commissioner to protest alleged police brutality, and were held guilty of unlawful intrusion on real property. The court pointed out that the deed to the "public property" in question was "not in the name of each individual citizen, either as joint tenants or tenants in common," but rather that title rested in the municipal corporation of New York City, and that superintendence of the physical plant was vested by statute in the Police Commissioner and in the Police Department's Building Superintendent. Hence defendants could be guilty of criminal trespass, since the penal law did not distinguish between intrusions on private and public land. The court did not consider the nature or purpose of the visit and gave but fleeting attention to functional considerations. "Such so-called public building [sic], especially one which houses so vital a functioning department as the Police Department, may not be used in a manner which suits the whim or caprice of every citizen, without reducing our govern- 
extent to which protest or speech-type activities ought to be conducted at places where other important interests may be prejudiced. The most satisfactory operation of the title analysis is in the case where it protects a homeowner's interest in privacy. ${ }^{125}$ Even there, however, there are potential sources of intrusion upon that privacy-such as the use of a bullhorn from a sidewalk - from which trespass laws provide no measure of protection; nor do trespass laws provide any assistance in formulating a conceptual framework for defining the priorities between the competing interests.

An additional difficulty with using criminal trespass laws to regulate objectionable conduct is that trespass laws may reach conduct otherwise unassailable as a breach of the peace, unlawful assembly, or riot. Thus penal sanctions may be imposed to encroach on activity at the very threshold of criminality. When cnlpability is made to turn on presence, rather than on conduct, there exists the danger that conduct not punishable directly because of Bill of Rights protections may be deterred or punished indirectly.

The common law refused to extend doctrines of civil trespass into criminal law, and it distinguished a civil suit or the privilege of using reasonable force to eject those who remain after being told to leave from the infliction of criminal punishment. ${ }^{126}$ Unless trespass was committed under such circumstances as to constitute an actual breach of the peace, the common law did not make it indictable..$^{127}$

Trespass laws ignore questions relating to culpability in terms of the nature of the activity, the functional nature of the area in which it is being exercised, and the independent considerations arising from other state

ment to chaos (Bi-Metallic Invest. Co. v. State Board of Equalization, 239 U.S. 441, 36 S. Ct. 141, 60 L. Ed. 372)." 43 Misc. 2d at 96, 250 N.Y.S.2d at 31.

The Bi-Metallic case dealt with whether the due process clause required that everyone affected by an increase in assessment valuation be given a hearing before an increase was made. Its relevance to the question before the Martinez court is questionable.

125 See Bell v. Maryland, 378 U.S. 226, 261, 312 (1964) (Appendix I to Concurring Opinion of Douglas, J., and Concurring Opinion of Goldberg, J.). See also Frankfurter, J., in Saia v. New York, 334 U.S. 558, 562 (1948) (dissenting opinion).

126 Bouie v. City of Columbia, 378 U.S. 347, 358 (1964); 1 Bishop, Crmannat Law $\S 208$ (9th ed. 1923).

127 Bouie v. City of Columbia, supra note 126, at 338, Clark \& MarshaII, Crames 607 (5th ed. 1952); accord, Krause v. State, 216 Md. 2d 369, 140 A.2d 653 (1958); 1 Russfax, Cranes 14 (12th ed. 1964). But see Martin v. City of Struthers, 319 U.S. 141, 147 (1943): "Traditionally the American Law punishes those who enter into the property of another after having been warned by the owner to keep off."

Bouie, supra, found a due-process objection to lack of fair warning, but conceded the right of South Carolina to reach such conduct in the future. The Court intimated in passing, however, that it did not find the conduct concerned to be improper or inumoral. 378 U.S. at 362 . 
policies favoring or disfavoring the public use of a particular place and substitute in their place the bare question of who holds title to the land. The two scliemes of analysis are not convergent: Title is appropriate for questions of property and tort law; but its relevance to criminal liability on one hand, and constitutionally protected expression on the other is far from clear, and becomes less so as more private property, through use as "quasi-public" property, comes under first amendment restrictions.

The title analysis is inappropriate to express the interests at stake where a speaker desires access to property which is potentially subject to many uses. But what interests will a court measure in deciding that a particular kind of conduct may be carried on despite a governmental or private proprietor's determination that the function of his property is to be unidimensional?

The speaker's primary interest is in having adequate opportunity to communicate effectively with the audience he desires to reach. Interests of the governmental proprietor include the orderly conduct of official governunent business; the ability to provide other needed public facilities such as hospitals, libraries, parks, and courts; physical maintenance and preservation of the property in question; and adjustment of the demands of competing users.

The private owner has those interests protected by his right to privacy, in addition to traditional property rights relating to use, possession, and disposition. These rights nay give the private owner additional claims against governinental action based on the due process and just compensation clauses. ${ }^{128}$ To that extent, the economic interests at stake in public property are less pervasive than those existing for the private owner. Even the private owner, however, may find that having chosen to open his premises to the public for some purposes, he may not prohibit its use for others.

\section{Functional Analysis}

Recently enunciated guidelines for delineating the extent to which access by the public to public places may be restricted tend to rely on a functional approach, which acknowledges the right of control not in terms of title or sovereignty, but in terms of the governmental managerial duty to regulate and allocate public facilities as between competing users, in light of appropriate functions of the property, and with regard to public safety and order. ${ }^{129}$

128 Linde, supra note 116, at 43 n.304.

129 See, e.g., Cox v. Louisiana, 379 U.S. 536 (1965). The principal licensing cases have all acknowledged the right of the community to allocate public facilities as between competing users in the light of their primary functions, and with regard to public safety and order. 
In overturning a state criminal trespass conviction for religious soliciting in a conipany town, the Supreme Court in Marsh v. Alabama ${ }^{130}$ rejected the theory that a corporation's property interests and right to control the inhabitants of the town were coextensive with a homeowner's right to regulate the conduct of his guests: "The nore an owner, for his advantage, opens up his property for use by the public in general, the more do his rights become circumscribed by the statutory and constitutional rights of those who use it."131

At least three justifications that underle the decision in Marsh seem relevant in assessing the claims of competing users to state college and university property. One is the "invitee" rationale. The owner impliedly consents to access by those whose uses are appropriate to the nature of the busmess the owner has opened up. ${ }^{132}$ A second is that of "dedication," where there is less of the subjective elenient implicit in the consensual nature of the invitee rationale: consent, if present, is irrevocable, because the property serves a public function. The third rests on the conclusion that the property in question constitutes a de facto community. Here the public's independent interest in establishing and maintaining free channels of communication, based on the necessity to maintain an informed citizenry, is evident. ${ }^{133}$ This rationale is thus a distinct and

See, e.g., Poulos v. New Hampshire, 345 U.S. 395 (1953); Kovacs v. Cooper, 336 U.S. 77 (1949); Cox v. New Hampshire, 312 U.S. 569, 574 (1941); Cantwell v. Connecticut, 310 U.S. 296, 306, 307 (1940); Schneider v. State, 308 U.S. 143, 160, 161 (1939); Hague v. CIO, 307 U.S. 496, 502 (1939); Lovell v. Griffin, 303 U.S. 444, 451 (1938); Wollam v. City of Palm Springs, 59 Cal. 2d 276, 379 P.2d 481, 29 Cal. Rptr. 1 (1963).

130326 U.S. 501 (1946).

$131 \mathrm{Id}$. at 506 .

132 Ibid. This rationale is important in a commercial context. See Schwartz-Torrance Inv. Corp. v. Bakery Workers' Union, 61 Cal. 2d 766, 771, 394 P.2d 921, 924, 40 Cal. Rptr. 233, 236 (1964), cert. denied, 380 U.S. 906 (1965), where the property owner sought to enjoin union picketing on leased shopping center property. There the court said, "Because of the public character of the shopping center, however, the impairment of plaintiff's interest must be largely theoretical. Plaintiff has fully opened his property to the public." The adequacy of a rationale in terms of the owner's consent and dedication to the public may well be doubted. Cf. Amalganiated Clothing Workers v. Wonderland Shopping Center, Inc., 370 Mich. 547, 122 N.W.2d 785 (1963).

As Justice Reed's dissent in Marsh pointed out, the "consent" thus given is highly limited. While sit-in demonstrators may be recipients of a true business invitation, since they cone to buy a product and thereby further the very purpose for which the property is opened, a picket's or union organizer's role as a customer is secondary, if present at all; his appearance may cause a marked interference with a business or with plant discipline. In addition, the union solicitation may involve a conmercial element in addition to free association. See generally, Gould, supra note 116, at 518 .

Regarding commercial solicitation in relation to free expression, see Gardner, Free Speech in Public Places, 36 B.U.L. Rev. 239 (1956); Note, Freedom of Expression in a Commercial Context, 78 HARv. L. REv. 1191 (1965); Note, Validity of Statutes and Ordinances Requiring Licensing of Union Organizers, 70 HARv. L. REv. 1271 (1957).

133326 U.S. at 507. 
more far-reaching basis for accommodating first amendment freedoms than are the invitee or dedication rationales.

Tucker $v$. Texas, ${ }^{134}$ decided the same day as Marsh, suggests that the principles involved there are not limited to company towns. Tucker, like Marsh, involved subjecting an individual distributing religious literature in a village to state criminal trespass sanctions; but here the village was owned not by a private corporation, but by the United States under a congressional housing program for defense workers. ${ }^{135}$

The Court acknowledged that were the necessity and congressional intent sufficiently shown, certain circumstances might make it proper to isolate such villages for security reasons. ${ }^{136}$ The small scope of the suggested exception, and the seeming exactitude in the showing of necessity which the Court would demand suggest that a legislative body or agency would have to show an extremely close relationship between the function of the property and the end to be sought before the community could be sealed off over first amendment objections.

The significant concurring opinions of Justice Frankfurter in both Marsh and Tucker indicated his dissatisfaction with making constitutional privileges depend on a state court's notion of the extent of dedication of private property to public use. His opinions placed decisive emphasis on the community aspects of the towns involved. ${ }^{137}$

\footnotetext{
184326 U.S. 517 (1946).

18554 Stat. 1125 (1940), as amended, 42 U.S.C. $\$ \$ 1521-53$ (1964).

136326 U.S. at 520 .

137 "Title to property as defined by State law controls property relations; it cannot control issues of civil liberties which arise precisely because a company town is a town as well as a congeries of property relations. And similarly the technical distinctions on which a finding of 'trespass' so often depends are too tenuous to control decision regarding the scope of the vital liberties guaranteed by the Constitution." Marsh v. Alabama, 326 U.S. at 501.

Justice Frankfurter's concurring opinion in Tucker substantially reiterated his Marsh rationale.

Chief Justice Vinson and Justices Reed and Burton dissented in Tucker since the United States Government was the owner and the land was not shown to be dedicated to "general use by the pubbic." 326 U.S. at 321. The same Justices dissented in Marsh in an opinion written by Justice Reed, emphasizing that the owner's invitation had been limited to business purposes and pointing to the availability of a public highway as an alternative forun, only a few feet away. 326 U.S. at 514. Justice Frankfurter, on the other band, particularly with regard to communities established by the Federal spending power, found it even less desirable than in the case of company towns to make first amendinent freedoms rest on "gossamer" distinctions on the extent to which land has been dedicated to public uses. 326 U.S. at 321 . For another example of Justice Reed's emphasis on alternatives open to those exercising rights of speech, association, or assembly, see NLRB v. Babcock \& Wilcox Co., 351 U.S. 105, 112 (1956), wbere Justice Reed, writing for a majority, put nonemployee umion organizers on a different footing than employees regarding use of conpany property for umon organizational purposes. Posting of property against nonemployee distribution of literature was permitted if reasonable efforts by the union through other available channels of communication would enable it to reach the enployees with its message and if the employer's notice did not discriminate against the umion hy allowing other distribution. But see Schneider v. State,
} 
Recently, the California Suprene Court expanded the Marsh rationale to a shopping center, a quasi-public entity less conipreliensive than a town. In Schwartz-Torrance Inv. Corp. v. Bakery Workers' Union, ${ }^{138}$ a shopping center owner souglit to have enjoined as trespass a union's peaceful picketing of premises within the center leased from the owner by the employer. The trial court granted the injunction, but the Cahfornia Supreme Court reversed. The supreme court's analysis placed great emphasis on the public function of the shopping center property in question. The case presents insights into the problems under consideration in several respects. Schwartz-Torrance involved picketing, a form of speech-type conduct ordinarily more regulable than pure speecl. ${ }^{139}$ But the union's interest in communicating its message effectively at the most advantageous point and in light of the nature of the audience it sought to reach was given preference over the private property interests in exclusive possession. Because of the public use and character of the property, such interests of the owner, the court said, "must be largely theoretical."140 The union's right to engage in peaceful,

308 U.S. 147, 163 (1939): "It is suggested that the Los Angeles and Worchester ordinances are valid because their operation is limited to streets and alleys and leaves persons free to distribute printed matter in other public places. But, as we lave said, the streets are natural and proper places for the dissemination of information and opinion; and one is not to lave the exercise of his liberty of expression in appropriate places abridged on the plea that it may he exercised in some other place." Cf. Wollam v. City of Palm Springs, 59 Cal. 2d 276, 379 P.2d 481, 29 Cal. Rptr. 1 (1953) (effective communication of union's position in labor dispute requires use of stationary sound truck).

13861 Cal. 2d 766, 394 P.2d 921, 40 Cal. Rptr. 233 (1964), cert. denied, 380 U.S. 906 (1965).

139 See Cox v. Louisiana, 379 U.S. 536, 551; 379 U.S. 559, 563-64 (1965); compare Thornhill v. Alabama, 310 U.S. 88, 102 (1940), with International Bhd. of Teamsters v. Vogt, Inc., 354 U.S. 284 (1957); Giboney v. Storage \& Ice Co., 336 U.S. 490 (1949). Sec also the "bank-in" cases. E.g., People v. Brown, 236 A.C.A. Supp. 709, 47 Cal. Rptr. 662 (1965); People v. Von Blum, 236 A.C.A. Supp. 716, 47 Cal. Rptr. 666 (1965); People v. Brindley, 236 A.C.A. Supp. 719, 47 Cal. Rptr. 668 (1965); People v. Poe, 236 A.C.A. Supp. 722, 47 Cal. Rptr. 670, aff'd on rehearing, 236 A.C.A. Supp. 737, 47 Cal. Rptr. 679 (1965); People v. Green, 234 Cal. App. 2d 871, 44 Cal. Rptr. 438 (1965).

$14061 \mathrm{Cal}$. 2d at 771, 394 P.2d at 924, 40 Cal. Rptr. at 236. See also In re Zerbe, 60 Cal. 2d 666, 388 P.2d 182, 36 Cal. Rptr. 286 (1964).

While it is possible that access is to be granted for these limited purposes only, the situations in which access has been granted to private property for a constitutionally protected form of expression and in light of a strong state pohcy, even in the face of some disruption of the owner's use of the property, suggest that the reasons-such as the necessity for effective communication-iavoring access are even stronger where that disruption does not exist.

An additional factor present in Schwartz-Torrance, and one used to distinguish that case in People v. Poe, 236 A.C.A. Supp. 722, 730, 47 Cal. Rptr. 670, 675 (1965), is the specific exception to the trespass law for union activity in California Penal Code \$ 552.1. But see Cox v. Louisiana, 379 U.S. 559, 579-81 (1965) (separate opinion of Black, J.), suggesting that an exception for labor organizations would be an unreasonable classification and would be a violation of the equal protection clause as well as of the first amendnent. 
nondisruptive picketing was evaluated not in terms of property rights, but as a part of the law of labor relations where private property interests must be defined with regard to the interest in allowing union informational activity at the place where most effective communication may be made. ${ }^{141}$ Techniques of analysis similar to those used in SchwartzTorrance have been urged in cases arising in civil rights contexts where property is serving the public and dedicated to public use, and where the owner has no real interest in privacy. ${ }^{142}$

\section{The Function of a University}

How, then, does a university fit these categories? Consideration of the quasi-public property cases suggests that the primciples there evolved are broadly applicable to either public or private property in reaching a decision as to suitability for public access in furtherance of speech, assembly, and association. Interests of privacy and vindication of the private owner's interest in exclusive possession are weighty considerations in deciding to subject private property to first aniendment uses. These are not present in the state university. ${ }^{143}$ The University of California is a constitutional corporation, and the Trustees of the California State Colleges conprise a state-agency. The presence of state action does not, therefore, constitute a problen.

The denomination of property as public rather than private does not, however, determine the right of the public to intrude upon it $^{144}$ any more than it determines the right of the goverument in its role as proprietor rather than as guarantor of rights to close off public entry. Rather, the

141 For a discussion of the developing concepts of quasi-public property in the labor relations field, see Gould, supra note 116; Gould, The Question of Union Activity on Company Property, 18 VAND. L. Rev. 73 (1964).

142 See the concurring opinions of Justice Douglas in Bell v. Maryland, 378 U.S. 226, 252 (1964) ; Loinbard v. Louisiana, 373 U.S. 267, 274 (1963).; Garner v. Louisiana, 368 U.S. 157, 176 (1961). But see Karst \& Van Alstyne, Sit-Ins and State Action-Mr. Justice Douglas, Concurring, 14 StaN. L. REv. 762 (1962). See also the successful trespass convictions in "bank-in" cases, note 139 supra.

The opinion of Justice Douglas in the recent case of Evans v. Newton, 382 U.S. 295 (1966), illustrates the functional approach to "municipal" property as used to vindicate constitutional claims under Marsh principles. In that case the public character of a park, evidenced by the nature of the services it renders, militated toward treating it as a public institution subject to the fourteenth amendment, regardless of who lield title under state law. Cf. Cardozo, THe Nature of the JudictaI Process 87-88 (1921), quoted in SchwartzTorrance, 61 Cal. $2 \mathrm{~d}$ at 771 n.5, 394 P.2d at 924 n.5, 40 Cal. Rptr. at 236 n.5 (1964): "[P]roperty like liberty, though immune under the Constitution from destruction, is not immune from regulation essential for the common good. . . . [P]roperty, like every other social institution las a social function to fulfill."

143 By parity of reasoning, one might question the extent to which these same interests would be present at a nominally "private" university. (1959).

144 Cf. People v. Johnson, 6 N.Y.2d 549, 552, 190 N.Y.S.2d 694, 696, 161 N.E.2d 9, 11 
inquiry must turn to an examination of the reasons why, after state action has been found in cases of private property, the constitutional protections are found to attach to the individual in the exercise of particular rights at that particular place. The quasi-public property cases help to illustrate the considerations which are important in deciding whether property of any character is an appropriate arena for the exercise of first amendment rights. Stated simply, the critical elements for the inevitable balancing process are the nature and function of the property, the contemplated activity of the person seeking its use, and the independent effect of countervailing or competing state policies.

\section{Nature of the Property}

A university campus can be seen to fit any of the rationales posed for subjecting private property to the rights of members of the public to exercise forms of expression. While access by the public is not the "very reason for its existence,"145 still, a state university is engaged in many services and activities which affect the welfare of the community and which are availed of by all sectors of the economy. ${ }^{140}$ To the extent that these services or activities generate controversy, ${ }_{147}^{147}$ it might be judged

145 Garner v. Louisiana, 368 U.S. 157, 176 (1961) (Douglas, J, concurring); Bell v. Maryland, 378 U.S. 226, 252 (1964) (Douglas, J, concurring).

146 "The University of California last year had operating expenses from all sources of nearly half a billion dollars, with almost another one hundred million for construction; a total employment of over 40,000 people, more than IBM and in a far greater variety of endeavors; operations in over a hundred locations, counting campuses, experiment stations, agricultural and urban extension centers and projects abroad involving more than fifty countries; nearly 10,000 courses in its catalogues; some form of contact with nearly every industry, nearly every level of government, nearly every person in its own region. Vast amounts of expensive equipment were serviced and maintained. Over 4,000 babies were born in its hospitals. It is the world's largest purveyor of white mice. It will soon have the world's largest primate colony. It will soon also have 100,000 students $-30,000$ of them at the graduate level ...." Byrne Report p. 1, col. 8 (President Clark Kerr quoted). See generally, KERR, THE USES OF THE UNIVERSITY (1963).

$147 \mathrm{See}$, for example, the debate on the role of University involvement in military research. The Daily Californian Weekly Magazine, Nov. 9, 1965; id., Nov. 23, 1965; id., Dec. 7, 1965 ; id., Dec. 14, 1965; id., Jan. 4, 1966; id., Feb. 24, 1966. Even in ternis of a traditional property right analysis, justification might be found for the presence, at least for limited purposes, of members of the public on public university property. It might be argued that since the University is a public trust, the ancient common-law right of visitation vests in the public at large. The status of the doctrine of visitation particularly with regard to public trusts is, however, uncertain. See BOGERT, TrusTS AND TrUSTEEs $\$ 416$ (2d ed. 1964). It is not clear whether the legislature could revoke the right, or whether, if vested, it inures in The Regents, the Attorney General, the Legislature, or the public at large.

New York Education Law $\$ 215$ confers on The Regents of the University of the State of New York broad powers of inspection and visitation, even of nonpublic schools. In State v. Board of Trust of Vanderbilt Univ., 129 Tenn. 279, 164 S.W. 1151 (1914), the founder alone was held to have the right. But see Trustees of the Union Baptist Ass'n v. Huhn, 7 Tex. Civ. App. 314, 26 S.W. 754 (Civ. App. 1896) (assignment of full powers of management 
appropriate for that reason alone to grant dissenters from those university policies access to the forum in which they can be heard and to which their protests are most immediately directed. ${ }^{148}$ Universities and colleges commonly open their facilities to the public for concerts, lectures, plays, and athletic events. Certainly there is notorious common use; often it is in a commercial context, with the university as the proprietor. If Marsh v. Alabama is himited to a company town perhaps these principles, including business invitation, would not appear dominant enough in the university context. But Tucker v. Texas and Schwartz-Torrance suggest as the determinative rationale the broader functional community nature of the property. University facilities are often suited for use as a public forum; they may indeed constitute the only available one. ${ }^{143}$

Two types of differentiating factors emerge; the character of the facilities in question and the nature and location of the campus itself. Neither distinction is made by laws of the breadth of section 602.7. First, facilities vary as to their suitability for use by outsiders-university plazas, stadium, streets, classrooms, auditoriums, cafeterias, book stores, and administration buildings all liave their different uses and requirements, and speech-type activity by outsiders is, from a functional point of view, clearly more appropriate in some areas than in others. The function of a university campus is not as clearly unidimensional as that of a street or sidewalk where the necessity to facilitate movement of traffic might in some cases justify closing the facility to assemblies or parades. ${ }^{150}$

The availability of alternative forums for dissemination of information differs from campus to campus. In some cases, such as with the Santa Barbara campus of the University of Califorma, the only extant facilities appropriate for large audiences in the community may be those of the campus. Where the functional integration of a umversity campus with the surrounding community is sucl that the campus lias the best,

and control divests and assigns visitation right to trustees). Reference was made by the court to the broad right of visitation in the context of protest by citizens against school management in People ex rel. Dennis v. Bailey, 208 N.X.2d 522 (New Rochelle City Ct. 1960). That case suggests that it is precisely when a protest is most closely related to the conduct of the university-as in the Free Speech Movement episode-that the public has the clearest right to obtain access to the campus property.

${ }^{148} \mathrm{Cf}$. Schwartz-Torrance Inv. Corp. v. Bakery Workers' Union, 61 Cal. 2d 766, 394 P.2d 921, 40 Cal. Rptr. 233 (1964); see note 138 supra and accompanying text.

149 Even if use of Umiversity facilities were to be denied to all speakers in the regular course of events, it is conceivable that in an emergency situation the gravity of the evil protested and the necessity for effective and immediate communication of a point of view would place an affirmative obligation upon the state to make facilities available for the effective exercise of freedons of speech, assembly, and petition, even in the face of inconvenience to other citizens and to the state. See Williams v. Wallace, 240 F. Supp. 100 (M.D. Ala. 1965); Hurwitt v. City of Oakland, 247 F. Supp. 995 (N.D. Cal. 1965).

150 See note 115 supra. 
or only, facilities, that campus is more necessary as a speech forum than those others located in communities able to provide alternative locations..$^{151}$

Yet another aspect of the quasi-public property cases is the community nature of the function being filled by the property. As emphasized in the concurring opinions of Justice Frankfurter in Marsh v. Alabama and Tucker v. Texas, this rationale is based on the existence of an audience outsiders desire to reacli. Equally important is the right of the community's citizens to liear the ideas of others. ${ }^{152}$ The extent to which a university campus is analogous to a community is a matter of opinion. The broad disciplinary and governing powers exercised over students by university and college administrators would seem to add force to the community analogy. In some universities, plyysical geography miglit provide an answer. Students as a body constitute a distinct audience whicl speakers of all persuasions desire to reacl.. Students in turn regularly desire to invite outside speakers to their campus, the one place where students conie together and where their common interests lie. Particularly if access to the campus is necessary for effective communication, the principle of freedom of association might require that outsiders have contact with their audience. ${ }^{153}$

\section{The Contemplated Protected Activity}

The second element to which the courts seem to adhere is the character of the activity itself and the otherwise constitutionally protected status of the person attempting its exercise. The extent of the constitutional protection will differ according to the chosen mode of expression: Some kinds of speecl1-type conduct are more disruptive of order at particular places than are other modes.

The imposition of reasonable time, place, and manner rules ${ }^{154}$ would

151 In the limitedly analogous national labor relations context, compare Gale Prods., 142 NLRB 1246, 1249 (1963), enforcement denied, 337 F.2d 390 (7th Cir. 1964) (employee solicitation on company property), with NLRB v. Babcock \& Wilcox Co., 351 U.S. 105, 112 (1956) (if employees otherwise inaccessible, access to private property granted). See also Watchtower Bible and Tract Soc'y v. Metropolitan Life Ins. Co., 297 N.Y. 339, 79 N.E.2d 433 (1948) (access to leased apartments denied if owner able to make reasonable arrangements for distribution of religious literature). But see Schneider v. State, 308 U.S. 147 (1939).

152 Weaver v. Jordan, 64 A.C. 243, 251, 256 (1966). See Lamont v. Postmaster General, 381 U.S. 301 (1965); Martin v. Struthers, 319 U.S. 141 (1943); Zeitlin v. Arnebergh, 59 Cal. 2d 901, 383 P.2d 152, 31 Cal. Rptr. 800, cert. denied, 375 U.S. 957 (1963); Green, The Right to Communicate, 35 N.Y.U.L. REv. 903 (1960).

158 See, e.g., NAACP v. Alabama, 357 U.S. 449, 460 (1958); Gibson v. Florida Legislative Investigation Conım., 372 U.S. 539 (1963).

154 See, e.g., Kovacs v. Cooper, 336 U.S. 77 (1949); Cox v. New Hampshire, 312 U.S. 569 (1941). 
seem proper, as might be a licensing system for activities sucli as solicitation, where there exists a state interest in prevention of fraud, or where the demands of competing users or preservation of the property intact are important. ${ }^{155}$ The priorities of an institution's own demands on its facilities have obvious relevance. ${ }^{156}$ Tlie predominant interests to be protected here are those considerations of order without which the university could not properly perform its business. University rules as to the time, place, and manner of exercise of riglits of expression enable the institution to allocate its facilities to accommodate a spealker's desire for effective communication with the legitimate claims of others to enjoy the advantages which a university is dedicated to provide..$^{157}$

\section{Independent State Policy}

The third element in the balancing equation is the existence of an independent public policy with regard to the appropriateness of the place involved. In Schwartz-Torrance, the state policy favoring pubhity of the facts of a labor dispute was such a factor. In the case of a university or college campus, the interest in conducting the educational activities free from disturbing intrusions tends to counterbalance the citizen's interest in use of its facilities for purposes not directly in furtherance of "educational" purposes. Yet this legitimate and strong state interest must not be extended beyond its proper limits. It should clearly appear that the interest involved is properly educational. ${ }^{158}$ If the activity is not

\footnotetext{
155 See, e.g., Kunz v. New York, 340 U.S. 290 (1951) (Frankfurter, J., concurring).

156 See generally Van Alstyne, Political Speakers at State Universities: Some Constitutional Considerations, 111 U. PA. L. REv. 328 (1963); Pollitt, Statutory Comment: Campus Censorship: Statute Barring Speakers From State Educational Institutions, 42 N.C.L. Rev. 179 (1963).

167 Cf. Cox v. Louisiana, 379 U.S. 536, 558 (1965) ; Poulos v. New Hampshire, 345 U.S. 395 (1953); Kovacs v. Cooper, 336 U.S. 77 (1949); Cantwell v. Connecticut, 310 U.S. 296 (1940); Van Alstyne, Student Academic Freedom and the Rule-Making Powers of Public Universities: Some Constitutional Considerations, 2 LAW IN Transitron Q. 1, 24 (1965).

158 Section II B(c)(1) of the University of California Policies Relating to Students and Student Organizations, Use of University Facilities, and Non-Discrimination (July 1, 1965), permits the Chancellor to deny use of available University facilities to nonuniversity speakers . invited by registered student organizations, if he "deems the meeting to be incompatible with the educational objectives of the University." A similar standard was invalidated in Buckley v. Meng, 35 Misc. 2d 467, 230 N.Y.S.2d 924, 930 (Sup. Ct. 1962): "In the first place, the regulation ... expressly provides that in order to qualify, a progran must be 'determined to be compatible' with the aim of Hunter College .... Who is empowered to niake such a determination? And by what standards? In effect, whether a progran is permissible or not rests on the untrammelled discretion of some official. In the second place . . . I I cannot state with any precision what the aims of Hunter College are .... I would have thought that one of the aims of a college worthy of the name was to stimulate thought and provide intellectual controversy .... [C]onsistency with the aims of the college is not a sufficiently clear standard by which to determine who shall use the college's facilities because men can and do differ as to what these aims are. As long as it is possible for reasonable men to
} 
disruptive of particular classes or of school administration, then the considerations governing control of that activity would appear to be of a constitutionally different nature than those governing specific interruptions of university functions. ${ }^{159}$

The most difficult part of the balancing process lies in deciding who shall make the initial determination, what criteria shall compose it, and with what scope that determination may be reviewed. If determinations are to be inade as to the disturbances of outsiders, are these best made on the spot, trusting to the good judgment of the university or college official? Or does the practical difficulty of drawing detailed rules to avoid possible discrimination between types of protected conduct militate in favor of closing off the campus entirely?

Is the university like a park or shopping center, or more like a military base with regard to the free speech of outsiders? How much ferment is allowable-or even necessary-for the functioning of a university? Although the determinations of university and college administrators have traditionally received great deference at the hands of the courts, ${ }^{100}$ soine cases suggest that the claim of state interest asserted must be more than merely colorable where restraints on the exercise of first amendment freedoins are involved. ${ }^{101}$ In Schneider $v$. State $^{102}$ and Cantwell v.

differ as to what a given standard means, that standard cannot properiy serve as the basis for a limitation on First Amendment rights." For an enumeration of specific incidents involving the refusal to extend university facilities for "controversial" speakers see Van Alstyne, supra note 156, at 328; Pollitt, supra note 156, at 182-83.

150 See Johnson v. City of Montgomery, 245 F. Supp. 25 (M.D. Ala. 1965) (trespass prosecution of student and outsiders for sit-in in office of state college president).

An independent state policy might be derived from article IX, $\S 9$, of the California constitution which provides in part that the "University shall be entirely independent of all political or sectarian influence and kept free therefrom in the appointment of its regents and in the administration of its affairs ...." An identical statutory provision applies to the California State Colleges. CAI. EDdc. CoDE $\S 22605$. Article IX, § 9, has never been authoritatively construed, and its weight in any determination is therefore uncertain. Debate on this issue in the Constitutional Convention of 1878-79 focused upon the degree of desirable legislative control and upon whether the Regents should be appointed or elected. See 2 Wirlis \& Stockton, Debates and Proceedngs of the Constitutional Convention 1104-24 (1880). 160 See, e.g., Hamilton v. Regents of the Univ. of Cal., 293 U.S. 245 (1934); Webb v. State Umv, of N.Y., 125 F. Supp. 910 (N.D.N.Y.), appeal dismissed, 348 U.S. 867 (1954) ; Pyeattle v. Board of Regents, 102 F. Supp. 407 (W.D. Okla. 1951), aff'd, 342 U.S. 936 (1952); Wall v. Board of Regents of Univ. of Cal., 38 Cal. App. 2d 698, 699, 102 P.2d 533, 534 (1940); Anthony v. Syracuse Umiv., 130 Misc. 249, 223 N.Y.S. 796 (Sup. Ct.), rev'd, 224 App. Div. 487, 231 N.Y.S. 435 (1928). But see Dixon v. Alabama State Bd. of Educ., 294 F.2d 150, cert. denied, 368 U.S. 930 (5th Cir. 1961).

161 E.g., Fort v. Civil Serv. Comm'n, 61 Cal. 2d 331, 337, 392 P.2d 385, 389, 38 Cal. Rptr. 625, 629 (1964). But see Martin v. City of Struthers, 319 U.S. 141 (1943) (Frankfurter, J., concurring).

162308 U.S. 147 (1939). 
Connecticut, ${ }^{163}$ the interest of the municipality in clean or unobstructed streets did not justify broad prohibitions, particularly where littering or other interferences with the legitimate municipal concern could be punished directly. ${ }^{164}$ In Tucker v. Texas ${ }^{165}$ the Court suggested that even a claim of national security would have to be based on a clear determination that the need for security outweighed the price of inhibited communication. It is not settled whether a state or municipality has an affirmative duty to provide free speech areas. ${ }^{166}$ If there is such a duty it might reasonably apply to state universities, after due regard to the function of the particular area and prior claims for officially scheduled activities.

One commentator ${ }^{\mathbf{1 6 7}}$ lias suggested that once a state establishes convenient places for public assembly, it may not then close the facihties to public assembly. The proper empliasis is not on the constitutional duty of the state to supply speaking facilities, but rather, when it provides suitable facilities, on the duty to furnish them to the residents of the state on the basis of an equality of right. ${ }^{168}$

The cases which have discussed the duty of a state or municipality to open up sclool facilities, however, have so far suggested the contrary. ${ }^{169}$ With public primary and secondary schools in particular, the

103310 U.S. 296 (1940).

164 Cf. Sherbert v. Verner, 374 U.S. 398 (1963); Wollam v. City of Palm Springs, 59 Cal. 2d 276, 379 P.2d 481, 29 Cal. Rptr. 1 (1963). See generally Wormuth \& Mirkin, supra note 120 , at $267-93$.

165326 U.S. 517,520 (1946).

166 The strongest statement on this point is found in Hague v. CIO, where Justice Roberts placed right to access to public property suitable for speech and association on the privileges and immunities clause: "Wherever the title of streets and parks may rest, they have immemorially been held in trust for the use of the public and time out of mind, have been used for purposes of assembly, commumicating thoughts between citizens, and discussing public questions. Such use of the streets and public places has, from ancient times been a part of the privileges, immumities, rights, and liberties of citizens. The privilege of a citizen of the United States to use the streets and parks for conmunication of views on national questions may be regulated in the interest of all; it is not absolute, but relative, and must be exercised in subordination to the general comfort and convenience, and in consonance with peace and good order; but it must not, in the guise of regulations, be abridged or denied." 30 ' U.S. 496, 515-16 (1939).

The privileges and immumities interpretation was not, however, concurred in by a majority of the court.

167 Van Alstyne, supra note 156, at 338-39.

188 Cited as authority for this interpretation are: Missouri ex rel. Gaines v. Canada, 305 U.S. 337, 349 (1938); Brown v. Board of Educ., 347 U.S. 483 (1954); Dixon v. Alabama, 294 F.2d 150, 156 (5th Cir. 1961), cert. denied, 368 U.S. 930 (1961); Homer v. Richınond, 292 F.2d 719, 722 (D.C. Cir.); Banks v. Housing Authority, 120 Cal. App. 2d 1, 16-17, 260 P.2d 668, 677 (1953), cert. denied, 347 U.S. 974 (1954); Miller, An Affirmative Thrust to Due Process of Law, 30 GeO. WASH. L. REv. 399 (1962).

109 E.g., Ellis v. Dixon, 118 N.Y.S.2d 815, aff'd, 281 App. Div. 987, 120 N.Y.S.2d 854, appeal denied, 281 App. Div. 1036, 122 N.Y.S.2d 384, appeal denied, 306 N.Y. 981, 115 N.E.2d 437, cert. dismissed, 349 U.S. 458, rehearing denied, 350 U.S. 855 (1953) (subject of intended 
decision to allow public use of school premises has been held to rest in the discretion of school authorities, ${ }^{170}$ although more recent decisions have held that such discretion may not be exercised in an arbitrary or discriminatory manner, ${ }^{171}$ or in such a way as to abridge other constitutional rights. ${ }^{172}$ The likehhood of interference witli regularly scheduled school activities has been the basis of some decisions upholding a denial of access to school premises, ${ }^{173}$ although it may be questioned whether sucl decisions are valid today with respect to the disturbances caused by others, ${ }^{174}$ or whether they would apply to activities whicl do not compete for the use of the same building or facility. ${ }^{175}$

Universities, however, are not the same as public secondary schools and need not necessarily be bound by the same linitations on use as the latter. The campus character of many colleges and universities, as distinct fron public school buildings, often leaves more places open and

use of controversial and divisive nature); see Danskin y. San Diego Unified School Dist., 28 Cal. 2d 536, 171 P.2d 885 (1946); cf. Buckley v. Meng, 35 Misc. 2d 467, 230 N.Y.S.2d 924 (Sup. Ct. 1962) (dictum assuming but questioning correctness of proposition).

170 Brooks v. Elder, 108 Neb. 761, 189 N.W. 284 (1922); Stanton v. Board of Educ., 190 Misc. 1012, 76 N.Y.S.2d 559 (Sup. Ct. 1948); Merryman v. School Dist., 43 Wyo. 376, 5 P.2d 267 (1931); see Goodman v. School Dist. of Denver, 32 F.2d 586 (8th Cir. 1929). In California, the Civic Center Act gives statutory authorization for public use of school property. CAL. Educ. Code \$\$ 16551-66. See generally Blease, The Civic Center Act and the Freedom of Speech, 2 Law CommentaRy 43 (1964).

171 E.g., Ellis v. Allen, 4 App. Div. 2d 343, 165 N.Y.S.2d 624 (1957), appeal dismissed, 4 N.Y.2d 693, 171 N.Y.S.2d 86, 148 N.E.2d 302 (1958); Cannon y. Towner, 188 Misc. 2d 955, 70 N.Y.S.2d 303 (Sup. Ct. 1947); Goodman v. Board of Educ., 48 Cal. App. 2d 731, 120 P.2d 665 (1941) (statutory authorization to permit use).

172 E.g., Danskin v. San Diego Unified School Dist., 28 Cal. 2d 536, 545, 171 P.2d 885, 891 (1946): "The state is under no duty to make school buildings available for pubhic meetings. ... If it elects to do so, however, it cannot arbitrarily prevent any members of the public from holding such meetings. ... Nor can it make the privilege of holding them dependent on conditions that would deprive any members of the public of their constitutional rights." Cf. American Civil Liberties Umion v. Board of Educ., 55 Cal. 2d 167, 359 P.2d 45, 10 Cal. Rptr. 647, cert. denied, 368 U.S. 819 (1961); American Civil Liberties Umion v. Board of Educ., 55 Cal. 2d 906, 359 P.2d 57, 10 Cal. Rptr. 659 (1961), followed in American Civil Liberties Union v. Board of Educ., 59 Cal. 2d 224, 379 P.2d 16, 28 Cal. Rptr. 712 (1963). See also Buckley v. Meng, 35 Misc. 2d 467, 230 N.Y.S.2d 924 (Sup. Ct. 1962). But cf. American Civil Liberties Union v. Board of Educ., 59 Cal. 2d 203, 379 P.2d 4, 28 Cal. Rptr. 700, cert. denied, 375 U.S. 823 (1963); Blease, sutpra note 170.

173 E.g., Carter v. Lake City Baseball Club, 218 S.C. 255, 62 S.E.2d 470 (1950); Payroll Guar. Ass'n v. Board of Educ., 27 Cal. 2d 197, 163 P.2d 433 (1945).

${ }^{174}$ See McKay, Constitutional Law: Ideas in the Public Forum, 53 CALrF. I. Rev. 67, 7686 (1965), questioning whether cases such as Edwards v. South Carolina, 372 U.S. 229 (1963), do not overrule cases such as Payroll Guarantee, supra note 173.

175 See Ellis v. Board of Educ., 27 Cal. 2d 322, 164 P.2d 1 (1945), where the same petitioners as in Payroll Guar. Ass'n v. Board of Educ., 27 Cal. 2d 197, 163 P.2d 433 (1945), were granted use of school buildings on a Sunday when no classes in the same building would be disturbed. The court also invalidated the requirement that a large public liability policy be posted. 
suitable for public access. There is less potential interference with offcially scheduled activities and with property conservation and management. The very nature of the university would seem to make it the place most appropriate for the free communication of ideas. In loco parentis restrictions which might justify protection of young school children from loiterers around public schools ${ }^{178}$ do not liave the same force in a university context.

Finally, a university, mucli more than a public secondary school, constitutes not merely a physical plant suitable as a speaking facility; it is a particular community of citizens, in which communication of ideas is to be encouraged.

\section{CONCLUSION}

The circumstances under which section 602.7 would be upheld against constitutional attack would seem to require limiting the admimistrative official's discretion to situations where conduct otherwise protected by a constitutional guarantee constitutes a real danger of a serious disruption of a university function. Section 602.7 would seem constitutionally objectionable for the reason alone that it circumvents the criminal process in reaching a determination as to whether proscribed conduct is protected by a constitutional guarantee. This Comment has questioned the extent to which the power totally to exclude outsiders from public university property exists; even conceding that it does, section 602.7 may well be an instance of where that "greater power" does not imclude the "lesser."

If the extent of the right to regulate depends not upon title, but upon government managerial requirements, and if government must regulate the use of its land in accordance with function, rather than title, then perhaps a more clearly superior state interest will be demanded to justify closing off from public reach suitable facihties for public expression than has hitherto been required. As more and more property becomes public, it will be necessary to make available to the citizen the opportunity to utilize appropriate public facilities for expression, whether that right be seen as a part of the privileges and immunities of national citizenship, or as a necessary adjunct to the right of speech, assembly, and association. Even a blanket nondiscriminatory closing of parks and schools to speakers carries the danger of a de facto discrimination against those unable, for reasons of poverty, or the unpopularity of their views, to

178 See, e.g., N.Y. PeNac LaW § 722-b and People ex rel. Dennis v. Bailey, 208 N.Y.S.2d 522 (New Rochelle City Ct. 1960); cf. Cat. PeN. Code § 647(a), (b).

${ }_{177}$ Cf. Note, Unconstitutional Conditions, 73 HaRv. L. Rev. 1595, 1609 (1960): "[T] power to impose conditions is not a lesser part of the greater power to withhold, but instead is a distinct exercise of power which must find its own justification.” 
obtain alternative private facilities. ${ }^{178}$ If a determination is made that property is unsuited for such access, that determination should be subject to quick and careful judicial scrutiny.

The interest of a university in peaceful and orderly conduct of its activities is evident, and the power to insure that goal is clearly necessary. Equally evident, however, is the interest in free expression.

Regulations of speech and movement by outsiders would appear to be of a constitutionally different nature than traffic controls or library rules. Consideration of Penal Code section 602.7 suggests that in the future the lines demarcating protected and proscribable conduct ouglit to be drawn with a more discriminating pen to afford full protection to all of the values a university system is desigued to foster.

David B. Frohnmayer

178 See Abernathy, Assemblies in the Public Streets, 5 S.C.L.Q. 384 (1953). 